Article

\title{
Evaluating the Effect of a Brewery By-Product as Feed Supplementation on the Quality of Eggs by Means of a Human Panel and E-Tongue and E-Nose Analysis
}

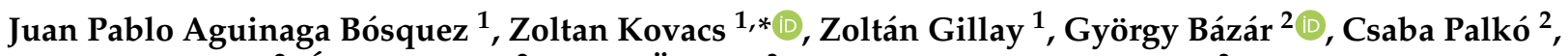 \\ Hajnalka Hingyi ${ }^{2}$, Éva Csavajda ${ }^{2}$, Márta Üveges ${ }^{3}$, Zsuzsanna Jókainé Szatura ${ }^{3}$, Iuliana Diana Barbulescu ${ }^{4,5}$, \\ Mihaela Begea ${ }^{4,6}$ and Tamás Tóth ${ }^{2,7}$ (1)
}

1 Department of Measurements and Process Control, Institute of Food Science and Technology, Hungarian University of Agriculture and Life Sciences, Somlói út 14-16, 1118 Budapest, Hungary; aguinaga.bosquez.juan.pablo@hallgato.uni-szie.hu (J.P.A.B.); gillay.zoltan@uni-mate.hu (Z.G.)

2 ADEXGO Ltd., Lapostelki u. 13, 8230 Balatonfüred, Hungary; george.bazar@adexgo.hu (G.B.); csaba.palko@adexgo.hu (C.P.); hajnalka.hingyi@adexgo.hu (H.H.); eva.csavajda@adexgo.hu (É.C.); tamas.toth@adexgo.hu (T.T.)

3 Department of Food Chemistry and Analytical Chemistry, Institute of Food Science and Technology, Hungarian University of Agriculture and Life Sciences, Villányi út 35-43, 1118 Budapest, Hungary; Uveges.Marta@uni-mate.hu (M.Ü.); Jokaine.Szatura.Zsuzsanna@uni-mate.hu (Z.J.S.)

check for updates

Citation: Aguinaga Bósquez, J.P.; Kovacs, Z.; Gillay, Z.; Bázár, G.; Palkó, C.; Hingyi, H.; Csavajda, É.; Üveges, M.; Jókainé Szatura, Z.; Barbulescu, I.D.; et al. Evaluating the Effect of a Brewery By-Product as Feed Supplementation on the Quality of Eggs by Means of a Human Panel and E-Tongue and E-Nose Analysis. Chemosensors 2021, 9, 213. https:// doi.org/10.3390/chemosensors9080213

Academic Editors: Run Zhang, Xiupei Yang, Yinyin Bao and Suban K. Sahoo

Received: 5 July 2021

Accepted: 3 August 2021

Published: 6 August 2021

Publisher's Note: MDPI stays neutral with regard to jurisdictional claims in published maps and institutional affiliations.

Copyright: (c) 2021 by the authors. Licensee MDPI, Basel, Switzerland. This article is an open access article distributed under the terms and conditions of the Creative Commons Attribution (CC BY) license (https:// creativecommons.org/licenses/by/ $4.0 /)$.
4 SC Pharmacorp Innovation SRL, 313 Splaiul Unirii Street, District 3, 030138 Bucharest, Romania; barbulescudia@yahoo.com (I.D.B.); ela_begea@yahoo.com (M.B.)

5 Faculty of Land Reclamation and Environmental Engineering (FIFIM), University of Agronomic Sciences and Veterinary Medicine of Bucharest, 59 Mărăşti Boulevard, District 1, 011464 Bucharest, Romania

6 Faculty of Biotechnical Systems Engineering, University Politehnica of Bucharest, 313 Splaiul Independentei, 060042 Bucharest, Romania

7 Agricultural and Food Research Centre, Széchenyi István University, Egyetem tér 1, 9026 Győr, Hungary

* Correspondence: kovacs.zoltan.food@uni-mate.hu

\begin{abstract}
The objective of our research was to evaluate the possible alteration of the organoleptic properties of eggs produced by hens (Lohmann Brown-Classic) fed with diets containing different doses of an industrial by-product enriched with organic zinc (Zincoppyeast, ZP): Control 0\%, ZP 2.5\%, and $\mathrm{ZP} \mathrm{5.0 \% .} \mathrm{Eggs} \mathrm{were} \mathrm{collected} \mathrm{after} 30$ days (batch 1 ) and 60 days (batch 2 ) of feeding with the experimental diets and subjected to chemical, microbiological, human sensory, e-nose, and e-tongue analyses. There was no significant difference among the microbiological status of eggs of the three groups, but there were significant differences $(p<0.05)$ in the fat $(9.5 \%$ vs. $9.3 \%)$ and protein contents (12.7\% vs. $13.4 \%$ ) of the Control and ZP 5.0\% groups, respectively. Human sensory analysis showed no clear change in the organoleptic characteristics of the eggs. Using linear discriminant analysis (LDA), the e-tongue could recognize the three groups of eggs in batch 1 and batch 2 with 95.9\% and $100 \%$ accuracy and had a prediction accuracy of $64.8 \%$ and $56.2 \%$, respectively. When the eggs were incubating at $50{ }^{\circ} \mathrm{C}$ or $80{ }^{\circ} \mathrm{C}$ before the e-nose analysis, the groups of eggs could be recognized with $98.0 \%$ and $82.7 \%$ accuracy, and predicted with $68.5 \%$ and $62.2 \%$ accuracy, respectively, using principal component analysis-based discriminant analysis (PCA-DA). The aroma compounds and respective sensory descriptors showing changes among the different groups of eggs (batch, storage, and feeding) were identified based on the e-nose analysis. The supplementation of laying hens' feed with the investigated industrial by-product can be applied without any substantial effect on egg quality, which can, however, be detected with advanced analytical methods.
\end{abstract}

Keywords: zinc; laying hen; chemometric; sensory profile analysis; PCA; LDA

\section{Introduction}

Eggs are consumed worldwide, as they are considered one of the most complete sources of nutrients for the human diet. They are considered a source of high-quality 
proteins, phospholipids, vitamins, and minerals. From an economic point of view, eggs are more affordable than other kinds of nutrient-rich foods or supplements [1,2]. Eggs from the species Gallus, from ancient times until present, have been a very important food, having more economic relevance than other types of egg marketed for consumption, such as duck, quail, and ostrich eggs [2].

Nutritional value is an important quality factor to be considered. Eggs can be considered a functional food, one that offers nutritional and health benefits beyond their original nutritional value. In this sense, for high-quality eggs, extensive research has been undertaken to confer health benefits by decreasing certain compounds (such as cholesterol) that can be prejudicial for health at high levels or by increasing some beneficial compounds such as protein content, omega-3, vitamins, and minerals [3-5].

In recent decades, egg enrichment has attracted great interest from researchers. Eggs can be enriched through nutritional management (feeding diet) of hens. For instance, incorporating flaxseed supplement (Linum usitatissimum) into the diets of hens resulted in egg enrichment with omega-3 [3], and the inclusion of dietary microalgae (Schizochytrium spp.) increased docosahexaenoic acid (DHA) omega-3 above $100 \mathrm{mg} / \mathrm{egg}$ [6]. Additionally, as described by Lima and Souza [4], who researched vitamin A enrichment of table eggs, the vitamin A concentration increased from $59 \mu \mathrm{g}$ to $75 \mu \mathrm{g}$ in eggs when vitamin A was incremented in supplements given to laying hens.

Zinc is also of high interest for egg enrichment as it is an important component in animals' and humans' diets. An inadequate diet may result in relatively fast occurrence of zinc deficiency as the body cannot store zinc reserves. Severe zinc deficiency is not common. However, mild deficiencies are more frequently reported around the world. Zinc is most often associated with antioxidant properties. Many studies have shown the relation between zinc in the diet and the risk of cancer. Moreover, zinc plays an important role in the human body: in the immune system, in cell differentiation, in DNA and RNA synthesis, and in enzyme activation or inhibition [7]. According to the National Academies of Sciences in 2001 [8], the Dietary Reference Intake (DRI) for zinc is $8 \mathrm{mg}$ /day for children aged 9-12 years and for females (except females 14-18 years old, who require $9 \mathrm{mg} /$ day); for males, $11 \mathrm{mg} /$ day is recommended. Dietary zinc is absorbed from the small intestine and distributed to the body. Bones and skeletal muscles are the major reservoir of zinc, storing $30 \%$ and $60 \%$, respectively; other organs such as the brain, liver, kidney, pancreas, spleen, etc., only account for 10\% [9]. In addition, it can be stated that zinc has a critical effect in immune function, in oxidative stress, in apoptosis, and in aging, and significant human disorders (e.g., atherosclerosis, several malignancies, neurological disorders, autoimmune diseases, and Wilson's disease) are associated with zinc deficiency. Thus, according to the literature, proper zinc consumption and/or supplementation may be beneficial during periods of greatest vulnerability, such as early childhood, pregnancy, and old age.

Among various publications about zinc enrichment in recent years, $\mathrm{Yu}, \mathrm{Q}$. et al., (2020) [5] evidenced an improvement in egg production and the effectiveness of eggs zinc-enhancing and antioxidant capacity in laying hens by using organic and inorganic zinc supplementation. For instance, chickens that received $600 \mathrm{mg} / \mathrm{kg}$ produced eggs with higher zinc content $(60 \mathrm{mg} / \mathrm{kg})$ than the controls $(300 \mathrm{mg} / \mathrm{kg})$. Another study showed that aged laying hens that received extra zinc $(80 \mathrm{mg} / \mathrm{kg})$ in their diet positively increased their zinc absorption, and the eggshell quality of their eggs also improved [10]. Similarly, for other avian species such as laying quails, inorganic and organic high-level zinc diets $(300 \mathrm{mg} / \mathrm{kg}$ ) positively affected the performance and egg shell quality (eggshell breaking strength and eggshell weight) [11]. The European Commission (2016) [12] regulates and authorizes the use of zinc as a feed additive for animal species. The allowed forms of zinc that are used for animal feeding are zinc acetate dehydrate, zinc chloride anhydrous, zinc oxide, zinc chelate of protein hydrolysates, zinc sulphate heptahydrate, zinc sulphate monohydrate, zinc chelate of amino acid hydrate, zinc chelate of glycine hydrate (solid), and zinc chelate of glycine hydrate (liquid). For hen feeding, a maximum content of $120 \mathrm{mg} / \mathrm{kg}$ of zinc is permitted for complete feed with a moisture content of $12 \%$. 
However, besides the evident advantages of enrichment, some unexpected quality factors such as the sensory attributes of the eggs may be also changed. Feed raw materials (e.g., soybean, linseed, fish oil) and by-products from the food and bioethanol industry (e.g., tomato peels, citrus meal, corn-DDGS, glycerol) can affect the quantitative and qualitative parameters of the eggs, as well as their organoleptic properties, such as color, odor, and taste. It is well known that feeding laying hens with oil sources rich in omega- 3 and omega-6 fatty acids (e.g., linseed/oil, fish oil) causes changes in the fatty acid profile of egg yolk, and the organoleptic properties (e.g., off-flavor) of the egg may also change [13-16]. Several studies aimed to evaluate the proportion of industrial by-products that can be used in feed rations for laying hens [17-23]. Determining how industrial origin by-products affect the production parameters of laying hens and the quality and organoleptic properties of their eggs is an essential task.

Traditionally, the organoleptic properties of eggs have been evaluated using sensory analysis, where human panelists act as instruments by measuring the quality of food products using the five senses (sight, hearing, smell, taste, and touch) [24]. For instance, Hayat et al., 2010 [25], using trained and untrained panelists, evaluated consumer acceptance of eggs from flaxseed-fed hens with additional vitamin E and BHT antioxidants. Kalus et al., 2020 [26] evaluated egg traits and consumer acceptance by applying a biochar diet supplementation to laying hens. Further, novel alternatives have appeared due to the necessity of developing reliable and precise detection systems. Electronic tongues (e-tongue) and electronic noses (e-nose) constitute promising analysis devices that simulate human senses [27]. The e-nose, designed to mimic the mammalian nose, uses sensors that interact with odor molecules (volatile compounds) and reads a signal that is sent to a computer; the resulting data are then analyzed using multivariate statistics [28]. The e-tongue works similarly; however, it reacts to non-volatile compounds in liquid instead [29,30]. For the e-tongue, scarce information is available regarding the sensory evaluation of eggs. Nevertheless, there is more information concerning the e-nose, particularly related to the profiling of egg volatiles form poultry species [31], the prediction of egg freshness [32,33], and volatile compounds of eggs from laying hens subjected to different diets [34].

Although there are studies available that test egg quality with sensory evaluation and electronic noses, there have been no studies on the evaluation of the possible change in quality of eggs produced by laying hens fed with zinc-enriched raw materials.

Another important factor to be mentioned is that modern society looks for environmentally friendly products that contribute to the sustainability of systems and carbon footprint reduction. A by-product of animal supplementation can have a positive effect on reducing contamination and procuring a circular economy. As mentioned by Ghisellini et al., 2016 [35], a circular economy not only procures social and environmental benefits but is also attractive for companies as it brings potential revenue opportunities. It is well known that industrial-origin by-products still contain nutrients (such as protein, fats, and macro- and microelements) and bioactive compounds (e.g., polyphenols, carotenoids, vitamins, organic acids, nucleotides, phytosterols); therefore, they are commonly used for animal feed or as fertilizer, or they are disposed of in landfills or incinerated [36]. The aforementioned authors also emphasized that the need for more sustainable practices, with reduced environmental impacts, towards the application of a circular economy in the food system, represents a key strategy for the future.

Therefore, the objectives of our study were the following: to evaluate differences in the sensory attributes of eggs produced by hens on isocaloric and isonitrogenous corn-soybean meal-based diets with different feed supplements; to assess whether a brewery industry by-product enriched with organic zinc, which constituted the feed supplement, causes laying hens to produce eggs with increased nutritional value; to determine if there is a significant alteration in the organoleptic properties of eggs by performing human sensory evaluation, and evaluation via e-nose and e-tongue. 


\section{Materials and Methods}

The laying hen feeding trial was carried out in accordance with the European Commission Council Directives (86/609/EEC) [37] and the Hungarian Act for the Protection of Animals in Research (Article 32 of Act XXVIII) [38].

A total of 900 56-week-old Lohmann Brown Classic (Lohmann Tierzucht GmbH, Cuxhaven, Germany) laying hens were housed in cages (EV 2240-EU, Big-Dutchman, HAT-AGRO Baromfitechnológia Kft., Győr, Hungary) within the same building with environmental control. The laying hens (average live weight: $1.88 \mathrm{~kg} \pm 0.12$ ) were divided into three groups (300 hens/group): Control (0\% Zincoppyeast), ZP 2.5\% (2.5\% Zincoppyeast), and ZP 5.0\% (5.0\% Zincoppyeast). Zincoppyeast represents yeast biomass in dried form, produced at the experimental level by SC AGSIRA SRL, Romania, using their spent brewing yeast mixed with the yeast biomass enriched with organic zinc produced by S.C. PHARMACORP INNOVATION SRL, Romania. Birds were fed with mash-form diets that complied with the NRC, 1994 [39], and the Lohmann Brown Classic Management Guide. The three groups were fed isonitrogenous and isoenergetic corn-extracted soybean meal-DDGS-wheat-based diets. The chemical composition of the compound feeds was determined by proximate analysis, which allowed the percentage determination of the compounds present in the feed; this is usually sufficient to establish the similarity of feed samples to prove whether they belong to the same category [40]. Based on the results of the proximate analysis, the calculated values of the diets were used as shown in Table 1, and their chemical composition and energy content is shown in Table 2. In this manner, the energy content of the three laying hen diets was the same, and the influence of Zincoppyeast at different levels could be evaluated. Feeds were analyzed for moisture content, crude protein, crude fat, crude fiber, calcium, phosphorus, and sodium content using the standard methods of the Association of Official Analytical Chemists (AOAC, 2006) [41]. Fresh water was administered each day ad libitum. In the compound feeds of the ZP 2.5\% group and the ZP 5.0\% group, extracted soybean meal was partially replaced by Zincoppyeast (yeast biomass enriched with zinc; SC AGSIRA SRL, Romania). The adaptation period to the formulated diets lasted for two weeks, followed by a three-month experimental period. The average daily egg production was above $91 \%$ in all groups during the whole experimental period.

Table 1. Component ingredients of experimental laying hen diets.

\begin{tabular}{|c|c|c|c|}
\hline Ingredient (\%) & Control & ZP $2.5 \%$ & ZP $5.0 \%$ \\
\hline Corn & 37.00 & 36.80 & 35.60 \\
\hline Extracted soybean meal (46\% CP) & 13.00 & 10.60 & 8.30 \\
\hline Corn-DDGS & 11.00 & 11.00 & 11.00 \\
\hline Wheat & 10.00 & 10.00 & 10.00 \\
\hline Extracted sunflower meal & 7.70 & 8.00 & 8.00 \\
\hline Limestone grit & 5.00 & 5.00 & 5.00 \\
\hline Corn germ meal & 5.00 & 5.00 & 5.00 \\
\hline Corn feed flour & 5.04 & 4.84 & 5.85 \\
\hline Limestone & 4.32 & 4.35 & 4.40 \\
\hline Zincoppyeast $^{1}$ & - & 2.50 & 5.00 \\
\hline $\mathrm{MCP}$ & 0.55 & 0.50 & 0.44 \\
\hline Soybean oil & 0.45 & 0.48 & 0.49 \\
\hline Salt & 0.32 & 0.32 & 0.32 \\
\hline Premix $^{2}(\%)$ & 0.30 & 0.30 & 0.30 \\
\hline L-lysine-HCL & 0.15 & 0.14 & 0.13 \\
\hline DL-methionine & 0.07 & 0.07 & 0.07 \\
\hline Lupro-Cid ${ }^{3}$ & 0.05 & 0.05 & 0.05 \\
\hline Vitafix Plus 4 & 0.05 & 0.05 & 0.05 \\
\hline
\end{tabular}

Control = 0\% Zincoppyeast, ZP 2.5\% = 2.5\% Zincoppyeast, ZP 5.0\% = 5.0\% Zincoppyeast. CP = crude protein DDGS = distiller's dried grains with solubles, MCP = monocalcium phosphate. ${ }^{1}$ SC AGSIRA SRL (Romania)

${ }^{2}$ Vitamin A 13,333,330 IU/kg; vitamin D $2500 \mathrm{IU} / \mathrm{kg}$; vitamin E 1,000,000 mg/kg; vitamin K 11,333 mg/kg; vitamin B1 $866.7 \mathrm{mg} / \mathrm{kg}$; vitamin B2 $1070 \mathrm{mg} / \mathrm{kg}$; vitamin B6 $1733 \mathrm{mg} / \mathrm{kg}$; folic acid $440 \mathrm{mg} / \mathrm{kg}$; vitamin B12 $9.7 \mathrm{mg} / \mathrm{kg}$; biotin $43.3 \mathrm{mg} / \mathrm{kg}$; calcium iodate $1333 \mathrm{mg} / \mathrm{kg}$; sodium selenite $100 \mathrm{mg} / \mathrm{kg}$; zinc oxide 33,333 mg/kg; iron carbonate 6666 mg/kg; manganese-oxide 33,333 mg/kg; copper sulphate 5333 mg/kg (producer: Agrifirm Magyarország Zrt., Környe, Hungary). ${ }^{3}$ BASF Hungária Kft. (Budapest, Hungary). ${ }^{4}$ Agrifirm Magyarország Zrt. (Környe, Hungary). 
Table 2. Chemical composition and energy content of experimental laying hen diets.

\begin{tabular}{cccc}
\hline Chemical Composition (\%) & Control & ZP 2.5\% & ZP 5.0\% \\
\hline Dry matter & 89.00 & 89.00 & 89.00 \\
Crude protein & 17.00 & 17.00 & 17.00 \\
Crude fat & 4.20 & 4.20 & 4.00 \\
Crude fiber & 4.80 & 4.80 & 4.80 \\
Crude ash & 12.90 & 12.90 & 12.90 \\
Starch & 34.50 & 34.50 & 34.50 \\
Sugar (total) & 3.00 & 3.00 & 3.00 \\
Total calcium & 3.70 & 3.70 & 3.70 \\
Total phosphorus & 0.52 & 0.53 & 0.53 \\
Sodium & 0.17 & 0.17 & 0.17 \\
SID Lys & 0.67 & 0.67 & 0.67 \\
SID M + C & 0.57 & 0.57 & 0.57 \\
SID Thr & 0.50 & 0.50 & 0.50 \\
SID Trp & 0.14 & 0.14 & 0.14 \\
SID Val & 0.68 & 0.68 & 0.68 \\
AMEn (MJ/kg) & 11.07 & 11.07 & 11.07
\end{tabular}

Control $=0 \%$ Zincoppyeast, ZP 2.5\% $=2.5 \%$ Zincoppyeast, ZP 5.0\% $=5.0 \%$ Zincoppyeast. SID Lys $=$ standardized ileal digestible lysine, SID Met + Cys = Standardized ileal digestible methionine + cysteine, SID Thr = Standardized ileal digestible threonine, SID Trp $=$ Standardized ileal digestible tryptophan, SID Val = Standardized ileal digestible valine, AMEn = apparent metabolizable energy corrected to zero nitrogen balance.

Eggs of the three groups were collected for evaluation on day 30 (batch 1) and day 60 (batch 2) of the experimental period (number of egg samples: $\mathrm{N}=90$ per batch for human sensory analysis, $\mathrm{N}=18$ per batch for e-tongue, and $\mathrm{N}=90$ per batch for e-nose). The collected eggs were handled as commercial eggs, disinfected with ozone, and stored at $10-14{ }^{\circ} \mathrm{C}$ until analysis. For human sensory analysis and e-tongue analysis, the samples were analyzed as fresh eggs ( 0 days of storage). Meanwhile, for e-nose analysis, the eggs were placed for 0,30 , and 60 days in fridge storage. Chemical and microbiological assays were performed on eggs collected on the same sampling days $(N=12 /$ batch for chemical analysis, $\mathrm{N}=30$ /batch for microbiological analysis).

The microbiological examination of the control (ZP 0\%) and experimental eggs (ZP $2.5 \%$ and ZP 5.0\%) was performed to enumerate mesophilic microorganisms (MSZ EN ISO 4833-1:2014), Enterobacteriaceae (MSZ ISO 21528-2:2007), Escherichia coli (MSZ ISO 166492:2005), Enterococcus spp. (AM 07:2011 Merck), and coagulase-positive staphylococci (MSZ EN ISO 6888-1:2008) counts and to determine the presence or absence of Salmonella spp. (MSZ EN ISO 6579:2006) and Listeria monocytogenes (MSZ EN ISO 11290-1:1996/A1:2005). The results are shown in Table 3.

Table 3. Microbiological properties of eggs in the three feeding diet groups.

\begin{tabular}{|c|c|c|c|c|c|c|}
\hline & \multicolumn{2}{|c|}{ Control } & \multicolumn{2}{|c|}{ ZP $2.5 \%$} & \multicolumn{2}{|c|}{ ZP $5.0 \%$} \\
\hline & Batch 1 & Batch 2 & Batch 1 & Batch 2 & Batch 1 & Batch 2 \\
\hline Mesophilic microorganism count, $\mathrm{CFU} \mathrm{g}{ }^{-1}$ & $<100$ & 10 & $<100$ & 20 & $<100$ & 10 \\
\hline Enterobacteriaceae, $\mathrm{CFU} \mathrm{g} \mathrm{g}^{-1}$ & $<10$ & $<10$ & $<10$ & $<10$ & $<10$ & $<10$ \\
\hline Escherichia coli, $\mathrm{CFU} \mathrm{g} \mathrm{g}^{-1}$ & $<1$ & $<10$ & $<1$ & $<10$ & $<1$ & $<10$ \\
\hline Enterococcus spp., CFU g ${ }^{-1}$ & $<10$ & $<10$ & $<10$ & $<10$ & $<10$ & $<10$ \\
\hline Salmonella spp., CFU/25 g & Negative & Negative & Negative & Negative & Negative & Negative \\
\hline Listeria monocytogenes, CFU/25 g & Negative & Negative & Negative & Negative & Negative & Negative \\
\hline Coagulase-positive Staphylococcus spp., CFU g ${ }^{-1}$ & $<10$ & $<10$ & $<10$ & $<10$ & $<10$ & $<10$ \\
\hline
\end{tabular}

Control = 0\% Zincoppyeast, ZP 2.5\% = 2.5\% Zincoppyeast, ZP 5.0\% = 5.0\% Zincoppyeast. Batch 1: day $30(\mathrm{n}=30)$; batch 2: day $60(\mathrm{n}=30)$.

There were no significant differences among the microbiological statuses of the three groups, which indicated their suitability for consumption. Significant differences were observed in the fat and protein content of the groups, as shown in Table 4. 
Table 4. Fat and protein content of eggs in the three feeding diet groups.

\begin{tabular}{ccccc}
\hline & Group & Average & S. Dev & Stat. Diff. * \\
\hline Fat content (\%) & Control & 9.48 & 0.04 & A \\
& ZP 2.5\% & 9.42 & 0.06 & AB \\
& ZP 5.0\% & 9.30 & 0.13 & B \\
\hline Protein content (\%) & Control & 12.67 & 0.22 & A \\
& ZP 2.5\% & 13.49 & 0.34 & B \\
& ZP 5.0\% & 13.35 & 0.38 & B \\
\hline
\end{tabular}

* Significant difference between means at $p<0.05$. Letters denote significant differences among the groups based on the one-way analysis of variance and Tukey HSD post hoc test analysis at $p<0.05$.

\subsection{Human Sensory Analysis of the Egg Samples}

For sensory evaluation, MSZ ISO 6658: 2018 was used as a reference test method [42] for the human organoleptic evaluation of the egg samples. The samples belonging to the three feeding groups (Control, ZP 2.5\%, and ZP 5.0\%) were evaluated by five trained reviewers according to an experimental design (Williams Latin Squares) in two replicates. The evaluation of the sensory characteristics or attributes was based on an intensity scale of 0 to 9 points. The eggs were evaluated in three presentations: raw eggs, boiled eggs, and fried eggs. A total of 21 sensorial characteristics were evaluated. The four characteristics for raw eggs were: albumin color, yolk color, yolk shape, albumin density. For boiled eggs, nine characteristics were evaluated, including: albumin color, yolk color, egg odor, strange odor, albumin flavor, strange taste, albumin flexibility, yolk creaminess. Eight characteristics were evaluated for fried eggs: yolk color, egg odor, sweet aroma, strange odor, egg taste, sweet taste, strange taste, and texture. In the sample preparation, boiled eggs were kept in boiling water for $10 \mathrm{~min}$. For fried eggs, oil was poured onto a pan and heated and then the previously beaten eggs were poured in and agitated during the cooking time.

\subsection{Electronic Tongue Analysis of the Egg Samples}

An Alpha Astree (AlphaMOS, Toulouse, France) electronic tongue (e-tongue) equipped with a 16-position auto-sampler was used to determine the taste profile of the egg samples; measurements were performed in the Hungarian University of Agriculture and Life Sciences, Institute of Food Science and Technology, Department of Measurements and Process Control. This device contains seven food-grade sensors (ZZ, JE, BB, CA, GA, HA, $\mathrm{JB})$ from which differences in potential changes are measured against the $\mathrm{Ag} / \mathrm{AgCl} 3 \mathrm{M}$ $\mathrm{KCl}$ reference electrode to detect and identify complex organic and inorganic compounds in the liquid sample. It uses fingerprint-like analysis technology to compare the general patterns of the samples measured on the seven sensors [30].

For the sample preparation, the eggs were crushed and the content poured into a porcelain dish and beaten for $1 \mathrm{~min}$. Afterwards, $2 \mathrm{~g}$ of the homogenized egg was placed in a $100 \mathrm{~mL}$ volumetric flask and filled up to the mark with distilled water. Six parallel samples as technical replicates were obtained from each of the three groups $(\mathrm{N}=18$ eggs $)$ for both tested batches and analyzed with the e-tongue. Due to the limited positions of the auto-sampler, the samples were placed in three separated sequences, and each of the sequences including one of the technical replicates of the three groups was tested four times, resulting in a total of 24 measurement points per sample group. The acquisition time of the samples was $120 \mathrm{~s}$ with a steering velocity of 3 , while the cleaning time of the sensors with distilled water was $20 \mathrm{~s}$ with a steering velocity of 6 .

\subsection{Electronic Nose Analysis of the Egg Samples}

The aroma profile measurements of the samples were performed with the Alpha MOS Heracles NEO electronic nose (e-nose) in the ADEXGO Ltd. Correltech ${ }^{\circledR}$ laboratory. The e-nose, designed for the analysis of volatile compounds, is an ultrafast chromatograph analyzer comprising two columns. Its operation begins with the odor concentration from 
samples in a cold trap. The trap is flushed and heated, and the concentrated odor is injected into the columns. In the columns, the volatile compounds are separated and detected by two flame ionization detectors (FID). AlphaSoft v17 software was used for the measurement and evaluation of the registered chromatograms by recording the retention time of the eluted molecules. The peak positions in the chromatograms are identified and defined as sensors, while odor intensity, associated with a volatile substance, is expressed by the Kovats index and determines the area under the peak. It was possible to identify characteristic compounds from the AroChemBase v8 database of AlphaSoft related to the Kovats index found [28]. In the database, "Food, Flavors, and Fragrances" were set as the application domains; additionally, the determination of compounds (associated with the sensors from the egg analysis) was performed by selecting the two highest-relevance indexes, allowing for a greater likelihood of correct volatile compound association.

The e-nose measurements were carried out by setting two different preheating temperatures of $50{ }^{\circ} \mathrm{C}$ and $80^{\circ} \mathrm{C}$ for the egg samples. The measurements were performed in the two available columns of the e-nose equipment, column MXT-5 and MXT-1701.

Similarly to the human sensory evaluation and e-tongue evaluation, we conducted the e-nose analysis on the fresh egg samples (0 days of storage). However, we also performed tests with egg samples stored in a fridge for 30 and 60 days, also separately, to determine if there was variation in the results according to storage time and feeding-mode group.

\subsection{Data Analysis}

The results of the human sensory evaluation were assessed by one-way analysis of variance (ANOVA) separately for each of the tested parameters, and where the ANOVA indicated significant differences $(p<0.05)$ among the three tested groups, Tukey HSD post hoc test was performed $(p<0.05)$ [43] as multiple comparison of the different groups.

For the results of the e-tongue evaluation, statistical analysis of the data was performed by calculating Euclidean distances in the seven-dimensional space (seven sensors) among the three treatment groups. Additionally, principal component analysis (PCA) was performed to explore multidimensional patterns. Linear discriminant analysis (LDA) was used for the classification of the three groups. The robustness of the LDA models was tested with three-fold cross-validation: the data were divided into a training set and a validation set, making sure that repeated measurements of the same sample were always kept together, i.e., not included at the same time in both training and validation sets. Two-thirds of the data were used to train the model; then, the remaining one third of the data was used as a validation set. This data splitting was carried out three times to ensure that each sample was used at least once in the calibration and validation set.

The data obtained from e-nose were evaluated using principal component analysis (PCA)-based discriminant analysis (PCA-DA). The significant sensors that most contributed to the separation of groups according to Kovats index were identified. As the two columns showed similar results for discrimination, column MXT-5 was chosen for the presentation of the results. The models were tested with three-fold cross-validation: the data were divided into a training set and a validation set similar to the approach described for the e-tongue analysis. The optimum number of principal components (PC) used as input variables for the discriminant analysis models was determined based on the average correct classification accuracies of training and validation. The number of PCs presented the highest correct classification accuracies and, at the same time, the lowest drop from training to validation was used to minimize the probability of overfitting.

The evaluation was carried out according to a combination of different factors to find the most relevant to report, also taking into account the results of the three-fold cross-validation: 2 batches $\times 3$ feeding groups (only for day 0 storage time), 3 feeding groups $\times 3$ storage time (by batch).

The data were analyzed using R-project software, version 4.0.3 [44]. 


\section{Results and Discussion}

\subsection{Results of Human Sensory Evaluation of the Egg Samples}

Figure 1 illustrates the ANOVA and Tukey test results for the human sensory analysis according to the three feeding groups (Control, ZP 2.5\%, and ZP 5.0\%), two batches, and three different forms of egg presentation (raw, boiled, and fried). In general, there were unmarked differences for the majority of sensory attributes between egg groups as the panelist described the 23 parameters analyzed as typical of fresh eggs.

\section{Batch 1}

a,

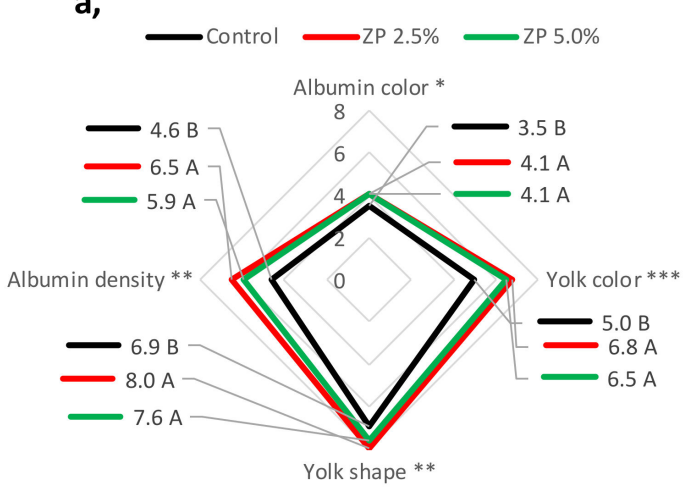

c,

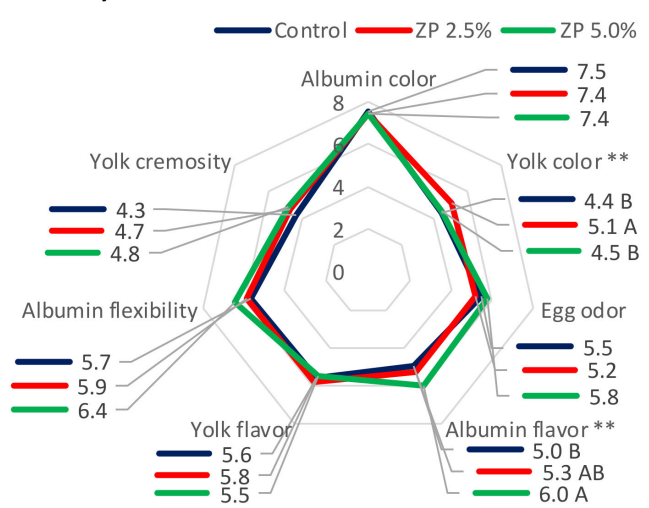

e,

FRIED EGG

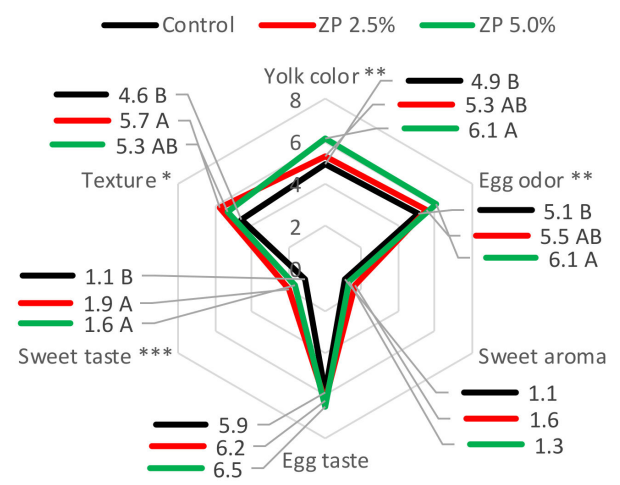

Batch 2

b,

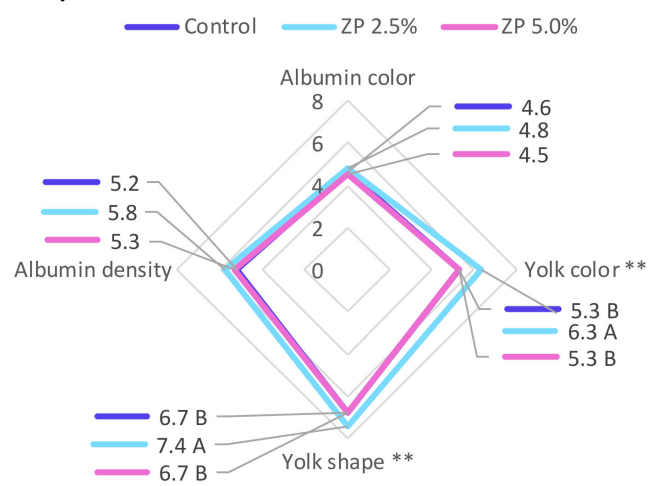

d,
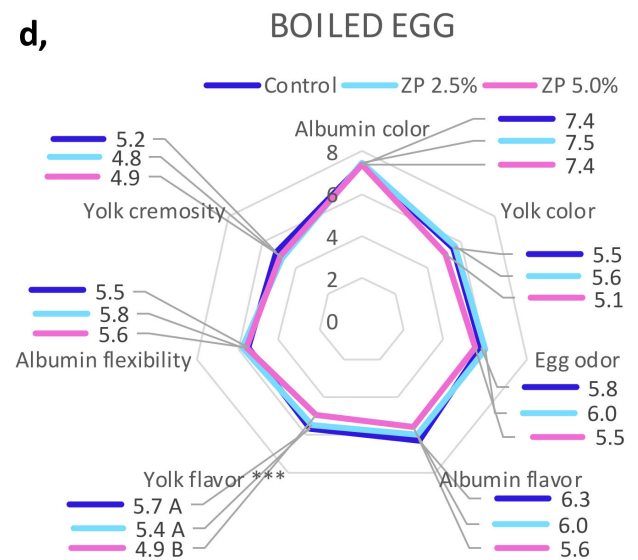

f, FRIED EGG

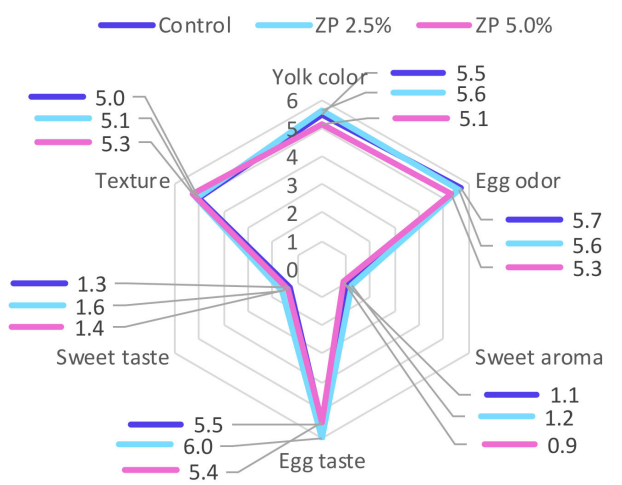

Figure 1. Human sensory analysis: Results from ANOVA and Tukey HSD (5\%) for eggs' sensory attributes according to three feeding groups (Control, ZP 2.5\%, and ZP 5.0\%), for batch 1 (a,c,e) and batch 2 (b,d,f), presented in different forms: raw egg $(\mathbf{a}, \mathbf{b})$, boiled egg $(\mathbf{c}, \mathbf{d})$, fried egg $(\mathbf{e}, \mathbf{f})$. Level of significant difference between groups for each attribute are given at $p$-value $>0.05$ (ns), $p$-value $<0.05\left(^{*}\right), p$-value $<0.01\left(^{* *}\right)$ and $p$-value $<0.001\left(^{* * *}\right)$. Groups marked with the same letter do not differ significantly. 
On one hand, as seen in Figure 1a, the samples from the first experiment (batch 1) presented significant differences for all the attributes of raw egg. The Control group presented lower values compared to the ZP 2.5\% group and the ZP 5.0\% group according to white color (more intense), yolk color (more intense), yolk shape (more convex), and protein density (higher density). Similarly, regarding the fried eggs (Figure 1e), significant differences were found for yolk color (more intense), egg odor (more intense), and sweet flavor (more intense); for these attributes, the Control group presented lower values on the scale with respect to the ZP 2.5\% and ZP 5.0\% groups. However, the boiled egg (Figure 1c) only presented a significant difference in yolk color (the ZP $2.5 \%$ group had a slightly more intense color than the Control and ZP 5.0\% groups) and white flavor (the ZP 5.0\% group had a slightly more intense flavor than the Control and ZP 2.5\% groups).

On the other hand, as seen in Figure 1b, the samples from the second experiment (batch 2) presented different results compared to the first experiment (batch 1). There were fewer attributes with statistically significant differences. For raw eggs, significant differences were found only for yolk color and yolk shape (the Control and ZP 5.0\% groups presented a slightly opaque color and a slightly less convex shape compared to the ZP $2.5 \%$ group). In Figure 1d, for boiled eggs, there were statistically significant differences only for the yolk flavor, whereas the Control group and the ZP 2.5\% group had more intense flavor compared to the ZP 5.0\% group. The fried eggs, as seen in Figure 1f, did not present statistically significant differences between groups.

The different results observed for the two series of experiments (batch 1 and batch 2) suggest a low level of differences among the samples (hardly detectable by the trained panelist) or a limitation in clearly differentiating the samples based on the selected sensory attributes.

\subsection{Results of E-Tongue Evaluation of the Egg Samples}

Figure 2 illustrates the calculated Euclidean distances in seven-dimensional space of the electronic tongue sensor signals for the three groups of the examined eggs separately for the two tested batches on a scale from 0 to 30 . For both series of experiments (batch 1 and 2), the greatest distance was found between the Control and ZP 5.0\% groups. For batch 1 , the distance between the Control group and ZP 5.0\% group was 22; for batch 2, the distance between the Control group and ZP 5.0\% group was 26. A larger Euclidean distance is relative to larger differences between groups. As a consequence, the organoleptic properties were more dissimilar between the Control and ZP 5.0\% groups than between the Control and ZP 2.5\% groups and between the ZP 2.5\% and ZP 5.0\% groups.

a,

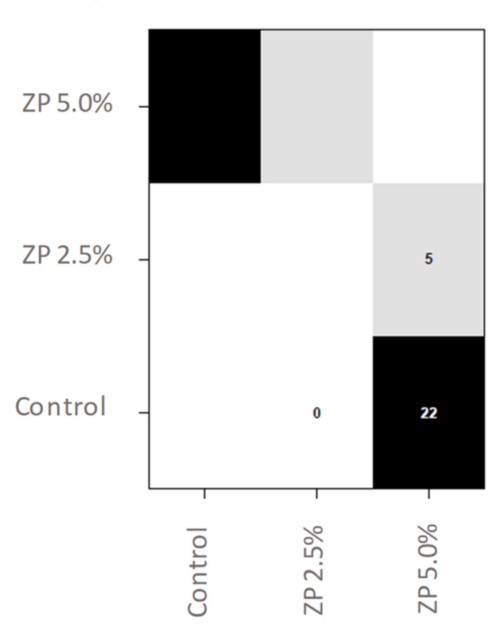

b,

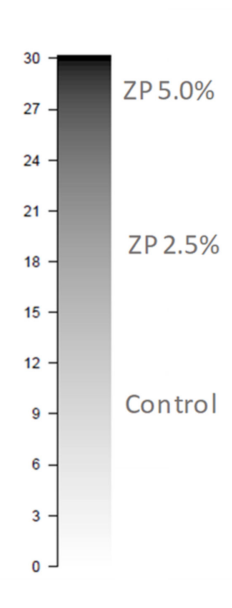

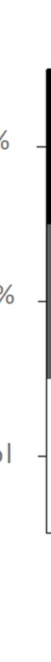

Batch 2

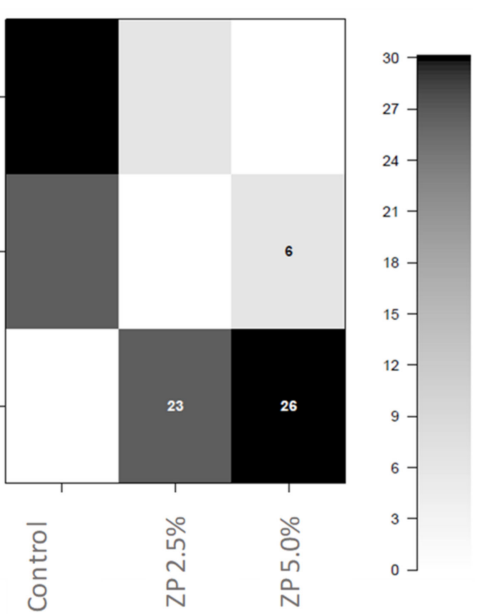

Figure 2. E-tongue: Euclidean distances for egg samples belonging to three feeding groups (Control, ZP 2.5\%, and ZP 5.0\%) for batch 1 (a) and batch 2 (b). 
As seen in Figure 3, the results of the principal component analysis did not show remarkable separation between the three groups of egg samples examined due to the relatively large standard deviation of the biological replicate samples within the groups. However, based on the combined analysis of the first three principal components, a slight differentiation of the Control group data points from the data points of the other two groups can be observed for both batches. This slight differentiation is more perceptible, especially in PC1 and PC3 for batch 1 (Figure 3b), where many of the data points from the Control group do not overlap with the ZP 5.0\% group. The PCA score plots of batch 2 (Figure 3c,d) also present slight separation of some of the data points of the Control group, especially from the ZP 5.0\% group, mainly based on PC1. The total variance between groups for batch 1 for PC1 was $66.09 \%$; for PC2, it was $13.22 \%$, and for PC3, it was $9.92 \%$; meanwhile, for batch 2 , it was $41.65 \%, 29.35 \%$, and $14.47 \%$ for PC1, PC2, and PC3, respectively.
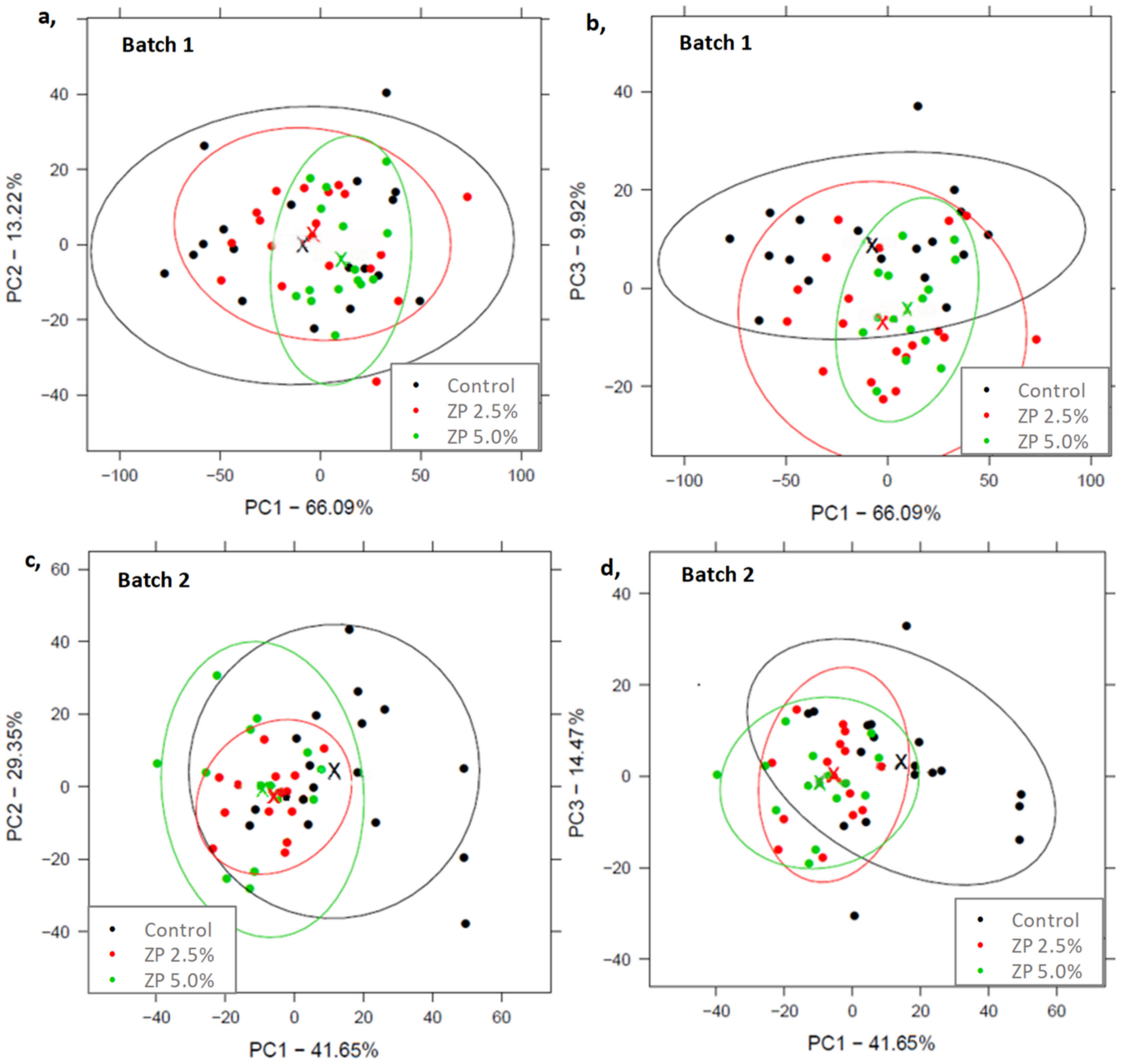

Figure 3. E-tongue: Principal component analysis for egg samples belonging to three feeding groups (Control, ZP 2.5\%, and ZP 5.0\%) for batch 1 (a), PC1-PC2, (b), PC1-PC3 and batch 2 (c), PC1-PC2, (d), PC1-PC3. Ellipses represent the 95\% confidence intervals of the respective groups, and $\mathrm{x}$ denotes the group centroids.

Similar to the results of the principal component analysis, a relatively large variation within each group of eggs can also be observed on the discriminant analysis score plots as presented by one of the three cross-validation sets (Figure 4). Due to the supervised nature of the method, a better separation of the three treatment groups (Control, ZP 2.5\%, and ZP $5.0 \%$ ) can be observed in both batches. In batch 1 , as can be seen in Figure $4 a$, the centers of each group marked with a cross show that the Control and ZP 2.5\% groups are closer, and ZP 5.0\% is more separated; better separation can be seen between the data points from the 
Control and ZP 5.0\% groups. In batch 2 (Figure $4 \mathrm{~b}$ ), the ZP 2.5\% and ZP 5.0\% groups are more overlapped, and the Control group is more separated.
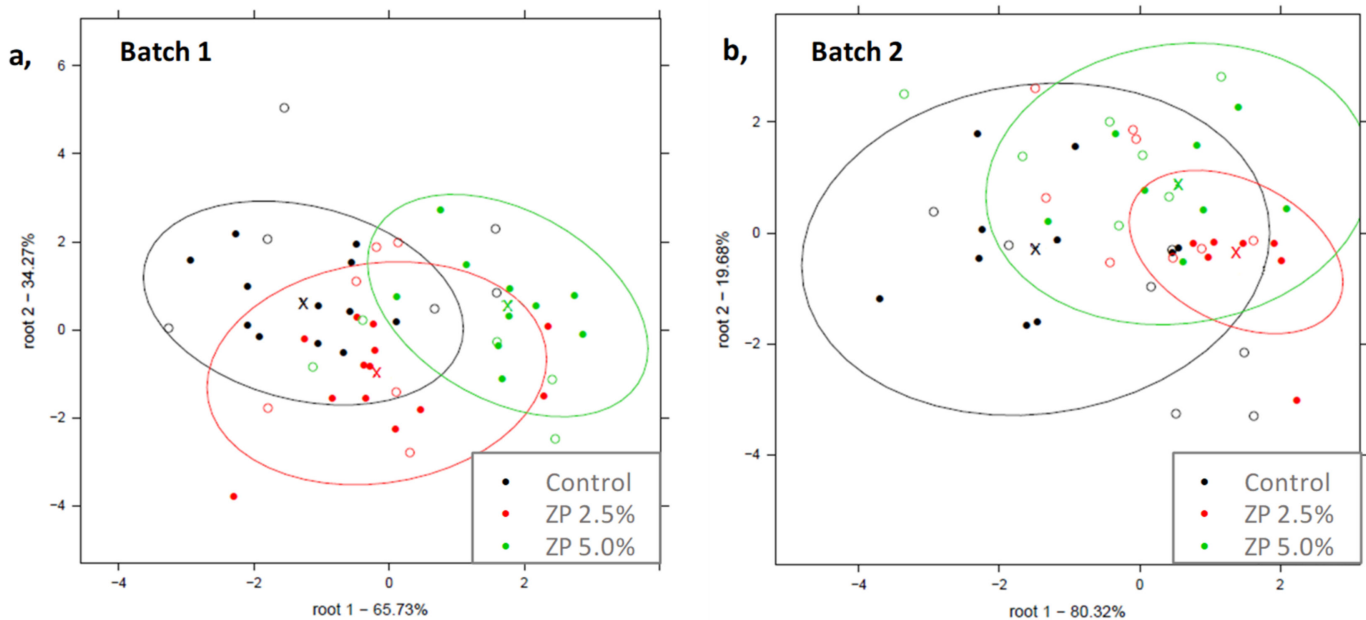

Figure 4. E-tongue: Discriminant analysis (from the third cross-validation) for egg samples belonging to three feeding groups (Control, ZP 2.5\%, and ZP 5.0\%) for (a) batch 1 and (b) batch 2. Ellipses represent the 95\% confidence intervals of the respective groups, and $\mathrm{x}$ denotes the group centroids. Solid and empty symbols represent the training and validation sets, respectively.

Table 5 shows the confusion table of the LDA models with the average values of each of the three technical replicates and their three cross-validation steps for batch 1 and batch 2 separately. There was an average recognition accuracy of $95.92 \%$ and a prediction accuracy of $64.81 \%$ for batch 1 and $56.23 \%$ and $100 \%$ for batch 2 , respectively. The modeling showed $100 \%$ recognition with respect to the separation of the three groups, except for batch 1 in the first sequence, where there were some misclassifications between ZP $2.5 \%$ and ZP 5.0\% and minor misclassifications for Control and ZP 5.0\%. However, the results of the three-fold cross-validation suggest that the separation between the three groups of eggs was not perfect, with a misclassification between adjacent groups for both sets of experiments. Nevertheless, the separation of the Control and ZP 5.0\% groups proved to be $100 \%$ effective for both sets of experiments (for almost all sequences).

Table 5. E-tongue: Confusion table for classification of egg samples belonging to three feeding groups (Control, ZP 2.5\%, and ZP $5.0 \%$ ) for batch 1 and batch 2 (average of three sequences).

\begin{tabular}{|c|c|c|c|c|c|c|c|c|c|}
\hline \multicolumn{6}{|c|}{ Batch 1} & \multicolumn{4}{|c|}{ Batch 2} \\
\hline $\begin{array}{c}\text { Average } \\
\text { accuracies }\end{array}$ & $\%$ & Control & $\mathrm{ZP} 2.5 \%$ & ZP 5.0\% & & $\%$ & Control & ZP $2.5 \%$ & ZP $5.0 \%$ \\
\hline \multirow{4}{*}{ Recognition $95.92 \%$} & Control & 97.64 & 0.00 & 0.00 & \multirow{3}{*}{ Recognition $100.0 \%$} & Control & 100.00 & 0.00 & 0.00 \\
\hline & ZP 2.5\% & 0.00 & 97.25 & 7.14 & & $\mathrm{ZP} 2.5 \%$ & 0.00 & 100.00 & 0.00 \\
\hline & $\mathrm{ZP} 5.0 \%$ & 2.36 & 2.75 & 92.86 & & ZP $5.0 \%$ & 0.00 & 0.00 & 100.00 \\
\hline & $\%$ & Control & ZP 2.5\% & ZP $5.0 \%$ & & $\%$ & Control & $\mathrm{ZP} 2.5 \%$ & $\mathrm{ZP} 5.0 \%$ \\
\hline \multirow{3}{*}{$\begin{array}{c}\text { Cross-validation } \\
64.81 \%\end{array}$} & Control & 46.02 & 15.89 & 4.72 & \multirow{3}{*}{$\begin{array}{c}\text { Cross-validation } \\
56.23 \%\end{array}$} & Control & 88.94 & 0.00 & 33.33 \\
\hline & $\mathrm{ZP} 2.5 \%$ & 39.74 & 72.95 & 19.81 & & $\mathrm{ZP} 2.5 \%$ & 5.53 & 61.95 & 48.87 \\
\hline & ZP 5.0\% & 14.25 & 11.17 & 75.47 & & ZP 5.0\% & 5.53 & 38.05 & 17.79 \\
\hline
\end{tabular}

\subsection{Results of E-Nose Evaluation of the Egg Samples}

For the e-nose analysis, when the results of the fresh and stored (30 days and 60 days) eggs were evaluated separately, slightly better discrimination of the different treatment groups was found for the fresh eggs ( 0 days of storage), as presented in Figure 5. Figure 5a,c show the PCA-DA score plot results achieved at $50^{\circ} \mathrm{C}$ and $80^{\circ} \mathrm{C}$ preheating temperatures for the e-nose analysis, respectively. In both preheating temperatures, clear separation of the samples of batch 1 and batch 2 was observed based on root 1 describing $97.46 \%$ and $87.80 \%$ of the total between-group variance for preheating at $50{ }^{\circ} \mathrm{C}$ and $80{ }^{\circ} \mathrm{C}$, respectively. Root 2 
presents $1.14 \%$ and $11.68 \%$ between-group variance for the two preheating temperatures, respectively, showing a clear tendency of separation of the different treatment groups. In both preheating temperatures and for both batches, better separation between the control groups and the ZP 5.0\% group was found.
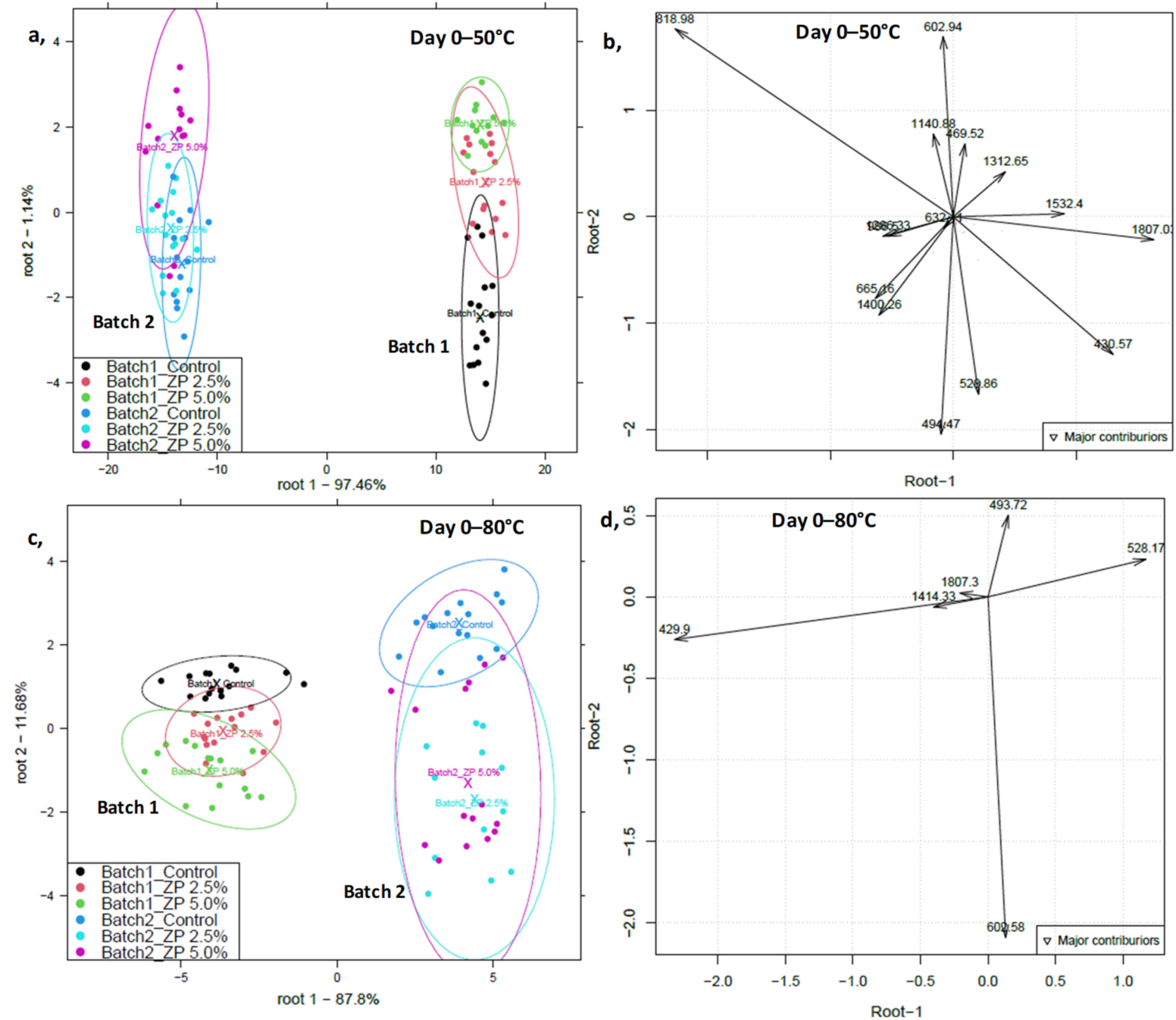

Figure 5. E-nose: PCA-DA $(\mathbf{a}, \mathbf{c})$ and sensor contribution $(\mathbf{b}, \mathbf{d})$ for the classification of fresh egg samples (day 0$)$ belonging to three feeding groups (Control, ZP 2.5\%, and ZP 5.0\%) and two different batches at two preheating temperatures (a) $50{ }^{\circ} \mathrm{C}$, $\mathrm{LV}: 23(30), \mathrm{n}=85$ and (c) $80^{\circ} \mathrm{C}, \mathrm{LV}: 4(30), \mathrm{n}=87$. Ellipses represent the $95 \%$ confidence intervals of the respective groups, and $x$ denotes the group centroids.

Figure $5 \mathrm{~b}, \mathrm{~d}$ show the sensors that contributed the most to the discrimination of the samples from 0 days of storage at $50^{\circ} \mathrm{C}$ and $80^{\circ} \mathrm{C}$ preheating temperatures.

At a preheating temperature of $50^{\circ} \mathrm{C}$, the main contributors to the separation between batch 1 and 2 were sensors 1807.03 linked to nootkatone (associated with banana, citrus, grape, sour fruit, spicy, and woody odors) and 2-hexadecanone (often connected with fruity odors); 1532.4 for cadina-1,4-diene (fruity, mango, spicy, wood) and methyldodecanoate (coconut, creamy, fatty, fruity, sweet, waxy); 1286.33 for isoborneol, acetate (balsamic), and pentyl hexanoate (fruity); and 986.5 for 3-octanone (butter, herbaceous, resinous) and 6-methyl-5-hepten-2-one (blackcurrant, boiled fruit, citrus, earthy, mushroom, rubber). For separation between the feeding groups, the main contributors were 602.94 linked to 2-butanol (fusel-alcoholic, oily, winey) and n-butanol (cheese, fermented, fruity, medicinal); 1140.88 for homofuraneol (caramelized) and methyl 3-pyridinecarboxylate (herbaceous, sweet, tobacco); 528.86 related to methyl acetate (blackcurrant, ethereal, fruity, solvent) 
and 2-methylpropanal (burnt, fruity, green, malty, pungent, spicy, toasted); and 494.47 for 2-propanone (fruity, glue, solvent) and propanal (ethereal, plastic, pungent, solvent). Additionally, the sensors that contributed to both the batch and feeding group separation were 818.98 associated with 2,4,5-trimethyl-3-oxazoline (musty odor) and 2-butanone, 3mercapto (onion or sulfurous odor); 430.57 linked to acetaldehyde (ethereal, fresh, fruity, pungent); 1312.65 for 1-methylnapththalene (earthy, green, musty, naphthyl) and cinamyl alcohol (oily); 1400.26 for tetradecane (alkane, fusel, mild herbaceous, sweet) and diphenyl ether (green); and 665.16 for n-butanol (cheese, fermented, fruity).

At a preheating temperature of $80^{\circ} \mathrm{C}$, for separation between batches, the major contributing sensors were 429.9 for acetaldehyde; 528.17 for methyl acetate and 2-methylpropanal; 1414.33 for linalyl butanoate (floral, pear, sweet) and (e)-beta-damascone (apple); and 1807.30 for nootkatone (banana, citrus, grape, sour fruit, spicy, woody) and 2-hexadecanone (fruity). The separation between groups was determined by 602.58 linked to 2-butanol (fusel-alcoholic, oily, winey) and n-butanol (cheese, fermented, fruity, medicinal); and 493.72 for 2-propanone.

The common sensors for the two preheating temperatures were 1807.03-1807.30, 602.94-602.58, 528.86-528.17, and $494.47-493.72$ for $50^{\circ} \mathrm{C}$ and $80^{\circ} \mathrm{C}$, respectively.

In contrast, the non-common sensors were 1532.40, 1286.33, 986.5, 1140.88, 469.52, $818.98,430.57,1312.65,1400.26,665.16$ for $50{ }^{\circ} \mathrm{C}$, and 1414.33 for $80{ }^{\circ} \mathrm{C}$.

Table 6 shows the confusion table of the PCA-DA models with the average values of each of the three technical replicates and their three cross-validation steps for batch 1 and batch 2 at $50{ }^{\circ} \mathrm{C}$ and $80^{\circ} \mathrm{C}$ preheating temperatures separately. There was an average recognition accuracy of $98.00 \%$ and a prediction accuracy of $68.49 \%$ for fresh eggs belonging to the feeding groups in batch 1 and 2 at $50{ }^{\circ} \mathrm{C}$; for $80^{\circ} \mathrm{C}$, there was $82.65 \%$ recognition accuracy and $62.22 \%$ prediction accuracy. However, the results of the three-fold crossvalidation suggest that the separation between the three groups of eggs was not perfect, with a misclassification between adjacent groups for both batches and both preheating temperatures. Nonetheless, there was a greater separation tendency between the Control and ZP $5.0 \%$ groups.

Table 6. E-nose: Confusion table for classification of fresh egg samples (day 0) belonging to three feeding groups (Control, ZP $2.5 \%$, and ZP $5.0 \%$ ) by batch and preheating temperature.

\begin{tabular}{|c|c|c|c|c|c|c|c|c|}
\hline \multicolumn{5}{|c|}{ Batch 1, $50{ }^{\circ} \mathrm{C}$} & \multicolumn{4}{|c|}{ Batch 2, $50{ }^{\circ} \mathrm{C}$} \\
\hline & $\%$ & Control & ZP 2.5\% & ZP 5.0\% & $\%$ & Control & $\mathrm{ZP} 2.5 \%$ & ZP 5.0\% \\
\hline \multirow{4}{*}{ Recognition $98.00 \%$} & Control & 100.00 & 0.00 & 0.00 & Control & 96.04 & 0.00 & 8.03 \\
\hline & $\mathrm{ZP} 2.5 \%$ & 0.00 & 100.00 & 0.00 & $\mathrm{ZP} 2.5 \%$ & 0.00 & 100.00 & 0.00 \\
\hline & ZP 5.0\% & 0.00 & 0.00 & 100.00 & ZP 5.0\% & 3.96 & 0.00 & 91.97 \\
\hline & $\%$ & Control & ZP 2.5\% & ZP 5.0\% & $\%$ & Control & ZP 2.5\% & ZP 5.0\% \\
\hline \multirow{3}{*}{$\begin{array}{c}\text { Cross-validation } \\
68.49 \%\end{array}$} & Control & 38.83 & 5.50 & 0.00 & Control & 58.73 & 0.00 & 23.50 \\
\hline & ZP $2.5 \%$ & 27.83 & 83.33 & 6.60 & ZP 2.5\% & 11.82 & 77.83 & 17.67 \\
\hline & ZP 5.0\% & 33.33 & 11.17 & 93.40 & ZP 5.0\% & 29.45 & 22.17 & 58.83 \\
\hline \multicolumn{5}{|c|}{ Batch $1,80^{\circ} \mathrm{C}$} & \multicolumn{4}{|c|}{ Batch $2,80^{\circ} \mathrm{C}$} \\
\hline & $\%$ & Control & $\mathrm{ZP} 2.5 \%$ & ZP $5.0 \%$ & $\%$ & Control & $\mathrm{ZP} 2.5 \%$ & ZP $5.0 \%$ \\
\hline \multirow{4}{*}{ Recognition $82.65 \%$} & Control & 100.00 & 14.78 & 0.00 & Control & 100.00 & 0.00 & 14.78 \\
\hline & ZP $2.5 \%$ & 0.00 & 74.11 & 14.78 & ZP $2.5 \%$ & 0.00 & 81.00 & 29.67 \\
\hline & ZP 5.0\% & 0.00 & 11.11 & 85.22 & ZP 5.0\% & 0.00 & 19.00 & 55.56 \\
\hline & $\%$ & Control & ZP 2.5\% & ZP $5.0 \%$ & $\%$ & Control & ZP $2.5 \%$ & ZP 5.0\% \\
\hline \multirow{3}{*}{$\begin{array}{c}\text { Cross-validation } \\
62.22 \%\end{array}$} & Control & 77.83 & 5.50 & 0.00 & Control & 100.00 & 13.40 & 33.33 \\
\hline & ZP $2.5 \%$ & 16.67 & 77.83 & 44.50 & ZP 2.5\% & 0.00 & 40.00 & 44.50 \\
\hline & ZP 5.0\% & 5.50 & 16.67 & 55.50 & ZP 5.0\% & 0.00 & 46.60 & 22.17 \\
\hline
\end{tabular}

Figure $6 a, c$ show the PCA-DA analysis of the e-nose tests at a $50{ }^{\circ} \mathrm{C}$ preheating temperature when the results of the fresh and stored (30 days and 60 days) egg samples were evaluated together. It shows a complete separation among the samples stored for 0 , 30 , or 60 days. However, overlapping of the different treatment groups (Control, ZP 2.5\%, ZP5.0\%) was observed in each case. 

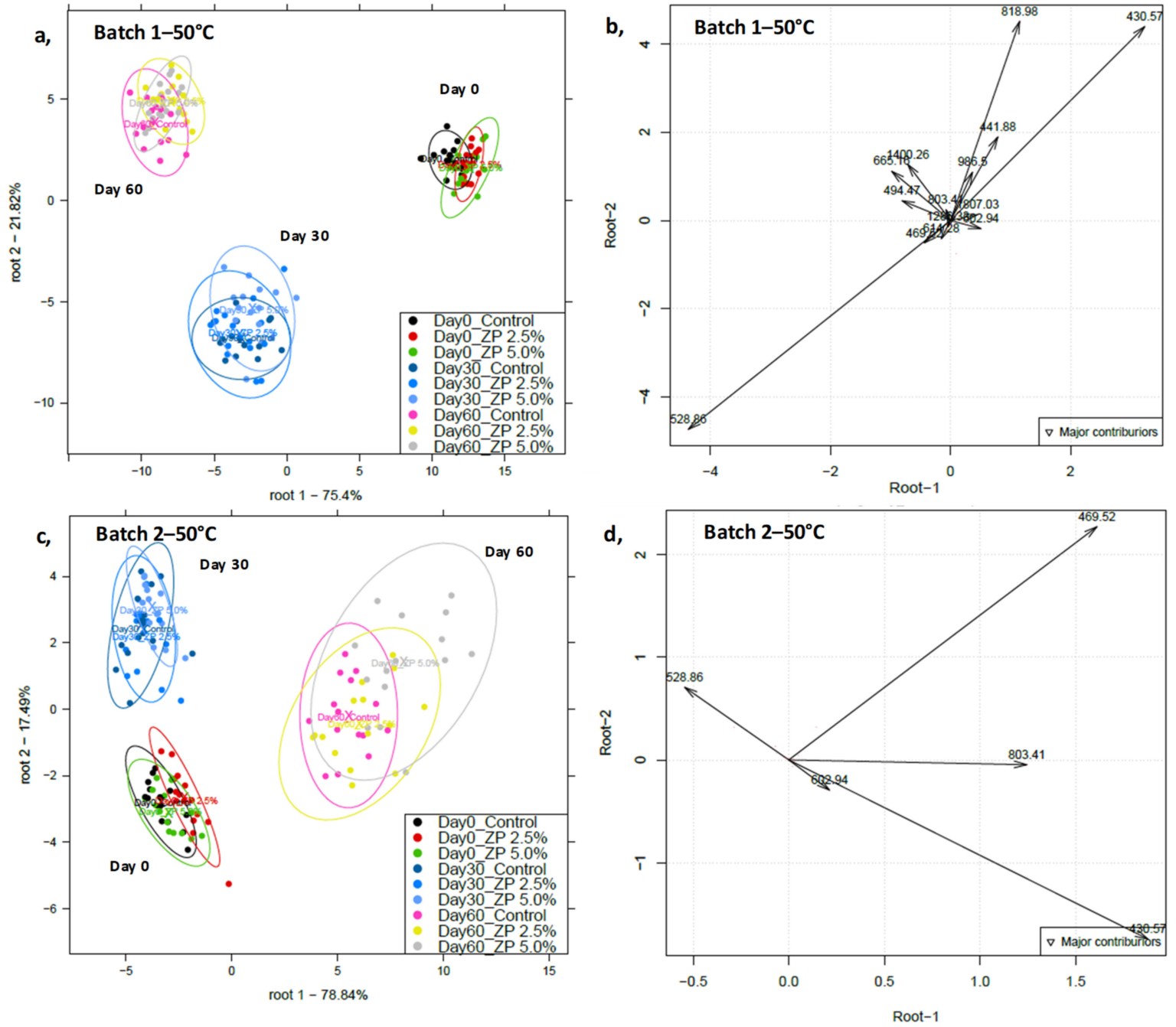

Figure 6. E-nose: PCA-DA $(\mathbf{a}, \mathbf{c})$ and sensor contribution $(\mathbf{b}, \mathbf{d})$ for the classification of egg samples belonging to three feeding groups (Control, ZP 2.5\%, and ZP 5.0\%) and storage time (0, 30, and 60 days). For batch 1 (a,b), LV: 20 (30), n = 132 and for batch 2 (c,d), LV: 4 (30), $n=133$; both batches were subjected to $50{ }^{\circ} \mathrm{C}$ preheating temperature. Ellipses represent the $95 \%$ confidence intervals of the respective groups, and $x$ denotes the group centroids.

Additionally, in Figure 6b,d, the main contribution sensors are presented. For batch 1, the main contribution sensors were 528.86 for methyl acetate (blackcurrant, etheral, fruity, solvent) and 2-methylpropanal (burnt, fruity, green, malty, pungent, spicy, toasted); 430.57 linked to acetaldehyde (ethereal, fresh, fruity, pungent); and 818.98 for 2,4,5-trimethyl3-oxazoline (musty) and 2-butanone, 3-mercapto (onion, sulfurous). There was also a presence of other major contributors with lower loadings such as 441.88, 494.47, 803.41, $469.52,602.94,665.16,1400.26,614.28,986.50,1807.03$, and 1286.33. All the main contributing sensors (with higher or lower loading) seem to be linked to the separation of fresh and stored (30 days and 60 days) egg samples. However, a minor contribution to the separation between feeding groups is also apparent.

The main contributing sensors for batch 2 were 469.52; 430.57 for acetaldehyde (ethereal, fresh, fruity, pungent); 602.94 linked to 2-butanol (fusel-alcoholic, oily, winey); 803.41 associated with 2-hexanol (fatty, fruity, winey) and hexanal (acorn, fatty, fishy, grassy, green, herbaceous, leafy, tallowy); 528.86 for methyl acetate and 2-methylpropanal (burnt, fruity, green, malty, pungent, spicy, toasted); and 602.94 for 2-butanol (fusel-alcoholic, oily, winey) and hexane (alkane, ethereal, kerosene).

A comparison between batch 1 and batch 2 shows that all main contributing sensors of batch 2 (469.52, 430.57, 602.94, 803.41, 528.86, and 602.94) were shared with those of 
batch 1; however, the other major sensors $(818.98,441.88,494.47,665.16,1400.26,614.28$, $986.50,1807.03$, and 1286.33) were only present in batch 1 but not in batch 2 .

It can be seen how acetaldehyde, methyl acetate, and 2-methylpropanal play an important role as volatile compounds in eggs, similar to what is presented in Figure 5. Some volatile compounds found, such as hexanal, 2,4,5-trimethyl-3-oxazoline and 2-butanone, 3 -mercapto, are more likely related to storage. The volatile compound concentration of fresh eggs changes and increases during storage [32]. The volatile components of egg yolks, such as esters, alkenes, alcohols, and nitrogenous compounds, are more likely to change [31]. The work in [33] reported an increase in hexanal during storage via the identification of volatile compounds from yolk. Other compounds such as dimethyl sulfide, dimethyl disulfide, dimethyl trisulfide, methyl thioacetate, methanol, ethanol, 1-propanol, acetone, 2-butanone, and ethyl acetate increase during storage.

Similarly, the PCA-DA analysis for the samples at a $80{ }^{\circ} \mathrm{C}$ preheating temperature (Figure $7 \mathrm{a}, \mathrm{c}$ ) shows complete separation between days of storage but overlap between feeding groups.
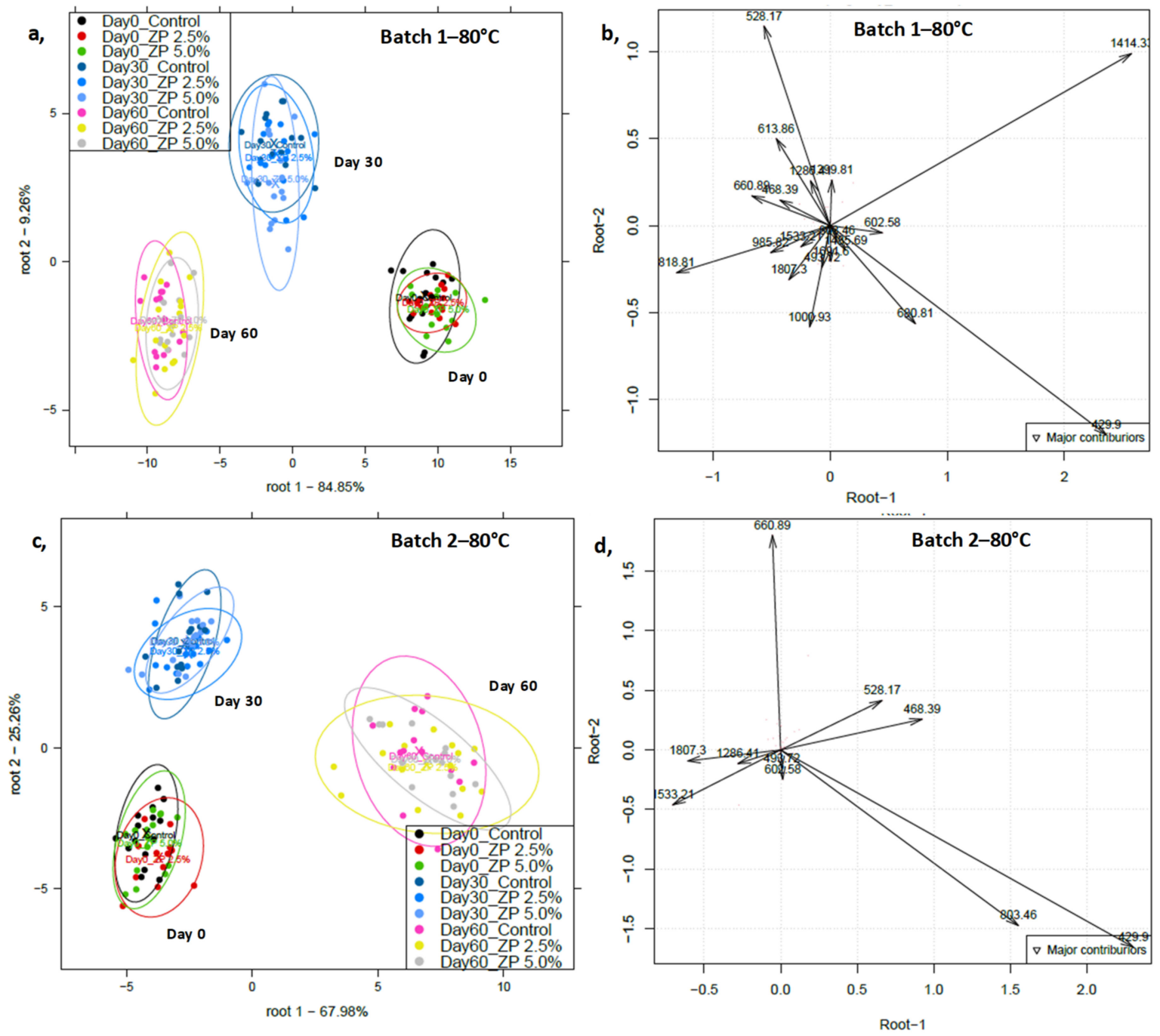

Figure 7. E-nose: PCA-DA $(\mathbf{a}, \mathbf{c})$ and sensor contribution $(\mathbf{b}, \mathbf{d})$ for the classification of egg samples belonging to three feeding groups (Control, ZP 2.5\%, and ZP 5.0\%) and storage time (0, 30, and 60 days). For batch 1 (a,b), LV: 18 (30), n = 134 and for batch 2 (c,d), LV: $11(30), n=130$; both batches were subjected at $80{ }^{\circ} \mathrm{C}$ preheating temperature. Ellipses represent the $95 \%$ confidence intervals of the respective groups, and $x$ denotes the group centroids. 
For batch 1 (Figure $7 \mathrm{~b}$ ), the main contributing sensors were 1414.33 related to linalyl butanoate (floral, Pear, sweet) and (e)-beta-damascone (apple); 429.9 for acetaldehyde (ethereal, fresh, fruity, pungent); 602.58 linked to 2-butanol (fusel-alcoholic, oily, winey); and 528.17 for methyl acetate (blackcurrant, etheral, fruity, solvent) and 2-methylpropanal (burnt, fruity, green, malty, pungent, spicy, toasted). The other main contributors with lower loading were 493.72, 803.46, 660.89, 468.39, 818.81, 1807.3, 680.81, 1533.21, 1000.93, 613.86, and 1691.6.

For batch 2 (Figure 7d), the main contributing sensors were 803.46 associated with 2hexanol (fatty, fruity, winey) and hexanal (acorn, fatty, fishy, grassy, green, herbaceous, leafy, tallowy); 429.9 for acetaldehyde; 468.39; 660.89 for 2-methylbutanal (almond, cocoa, green, malty, strong burnt); 602.58 for 2-butanol; 1807.3 for nootkatone and 2-hexadecanone; 1533.21 for cadina-1,4-diene and methyldodecanoate; 528.17 for methyl acetate and 2methylpropanal; 493.72 for 2-propanone and propanal; and 1286.41 for isoborneol, acetate, and pentyl hexanoate. The sensors 429.9, 602.58, 803.46, 468.39, 660.89, 1807.3, 1533.21, and 493.72 were common for batch 1 and 2 . On the other hand, sensors 818.81, 680.81, $1000.93,613.86$, and 1691.6 were only present in batch 1 ; sensors 528.17 and 1286.41 were only present in batch 2 .

The contribution of the sensors is mostly linked to the separation of fresh and stored (30 days and 60 days) egg samples. However, a minor contribution to separation between feeding groups was also apparent. This is similar to the analysis of samples carried out at $50{ }^{\circ} \mathrm{C}$ preheating temperature (Figure 6).

Table 7 shows a summary list of the major contributing sensors of egg volatile compounds as results of the e-nose data analysis. The egg volatile compounds found in this research are comparable to those reported by several researchers [33,34,45-47]. Sensors 429.9 and 430.57 for acetaldehyde (ethereal, fresh, fruity, pungent); 528.17 and 528.86 for methyl acetate (blackcurrant, etheral, fruity, solvent) and 2-methylpropanal (burnt, fruity, green, malty, pungent, spicy, toasted); and 602.58 2-butanol (gusel-alcoholic, oily, winey) were revealed to be important egg volatile compounds in this work. Other important contributors were sensors 818.98 associated with 2,4,5-trimethyl-3-oxazoline (musty) and 2-butanone, 3-mercapto (onion, sulfurous); 1807.03 linked to nootkatone (banana, citrus, grape, sour fruit, spicy, woody) and 2-hexadecanone (fruity); 803.41 and 803.46 associated with 2-hexanol (fatty, fruity, winey) and hexanal (acorn, fatty, fishy, grassy, green, herbaceous, leafy, tallowy); 1414.33 related to linalyl butanoate (floral, pear, sweet) and (e)-beta-damascone (apple); and 660.89 for 2-methylbutanal (almond, cocoa, green, malty, strong burnt), 468.39, 469.52.

Several studies refer to aldehydes as important volatile compounds of eggs. Their presence has been reported in scrambled eggs [46] and also in cooked eggs [45]. Moreover, volatile aldehydes are the most abundant in cooked egg yolks, and few are present in egg whites [45]. The authors found that the major aldehyde in egg yolk and whole egg volatiles was 2-methylpropanal. Other researchers [34,48] also found the abundant presence of aldehydes as volatile flavor components of eggs. Similar results were found in this research, with a major prevalence of acetaldehyde, methyl acetate, and 2-methylpropanal. Other compounds such as ketones and 2-propanone (acetone) were found in whole eggs and egg whites. Additionally, this suggests a greater presence of amino acids in egg white than egg yolk; certain amino acids have an important role in the formation of 2-methylbutanal. On the other hand, alcohols have a smaller presence in the whole egg; the majority of alcohols are mostly present in the egg yolk and are associated with lipid oxidation [34,45]. In our study, the alcohols present as egg volatile compounds with the greatest prevalence were 2-butanol (fusel-alcoholic, oily, winey) and 2-hexanol (fatty, fruity, winey). 
Table 7. E-nose: Summary of the sensory contribution results (including related volatile compounds/sensory description) from the MXT-5 column for egg sample classification.

\begin{tabular}{|c|c|c|c|c|}
\hline MXT-5 & C-S & Volatile Compounds & Sensory Description & Discrimination Tendency \\
\hline 429.90 & 428 & Acetaldehyde & Ethereal, fresh, fruity, pungent & $\begin{array}{c}\text { Figure 5: (b) B/G-50 }{ }^{\circ} \mathrm{C} \text {; (d) B- } 80{ }^{\circ} \mathrm{C} \text {; } \\
\text { Figure 6: (b,d) } \mathrm{D}^{*}-50^{\circ} \mathrm{C} \text {; }\end{array}$ \\
\hline 430.57 & 425 & Methanol & Pungent & Figure $7:(b, d) D^{*}-80^{\circ} \mathrm{C}$ \\
\hline 441.88 & $\begin{array}{l}448 \\
448\end{array}$ & $\begin{array}{c}\text { Ethanol } \\
\text { Methanethiol }\end{array}$ & $\begin{array}{l}\text { Alcoholic, ethanol, pungent, sweet } \\
\text { Alcoholic, ethanol, pungent, sweet }\end{array}$ & Figure $6:(b) D^{*}-50{ }^{\circ} \mathrm{C}$ \\
\hline 469.52 & & Not found & & \\
\hline 494.47 & $\begin{array}{l}498 \\
499\end{array}$ & 2-propanone (or acetone) & $\begin{array}{l}\text { Fruity, glue, solvent } \\
\text { Etherwal, plastic, pungent, solvent }\end{array}$ & $\begin{array}{c}\text { Figure 5: (b) G-50 }{ }^{\circ} \mathrm{C} ;(\mathrm{d}) \mathrm{G}-80{ }^{\circ} \mathrm{C} ; \\
\text { Figure 6: (b) } \mathrm{D}^{*}-50{ }^{\circ} \mathrm{C} ; \\
\text { Figure } 7:(\mathrm{b}, \mathrm{d}) \mathrm{D}^{*}-80^{\circ} \mathrm{C}\end{array}$ \\
\hline 528.17 & 522 & 2-methylpropanal & $\begin{array}{l}\text { Blackcurrant, ethereal, fruity } \\
\text { Burnt, fruity, green, malty, pungent, spicy, } \\
\text { toasted }\end{array}$ & $\begin{array}{l}\text { Figure 5: (b) } \mathrm{G}-50{ }^{\circ} \mathrm{C} ;(\mathrm{d}) \mathrm{B}-80^{\circ} \mathrm{C} \text {; } \\
\text { Figure 6: (b,d) } \mathrm{D}^{*}-50{ }^{\circ} \mathrm{C} ; \\
\text { Figure } 7:(\mathrm{b}, \mathrm{d}) \mathrm{D}^{*}-80^{\circ} \mathrm{C}\end{array}$ \\
\hline $\begin{array}{l}602.58 \\
602.94\end{array}$ & 600 & $\begin{array}{l}\text { 2-butanol } \\
\text { Hexane }\end{array}$ & $\begin{array}{l}\text { Fusel-alcoholic, oily, winey } \\
\text { Alkane, ethereal, kerosene }\end{array}$ & $\begin{array}{l}\text { Figure 5: (b) G-50 }{ }^{\circ} \mathrm{C} ;(\mathrm{d}) \mathrm{G}-80^{\circ} \mathrm{C} ; \\
\text { Figure 6: }(\mathrm{b}, \mathrm{d}) \mathrm{D}^{*}-50^{\circ} \mathrm{C} ; \\
\text { Figure } 7:(\mathrm{b}, \mathrm{d}) \mathrm{D}^{*}-80^{\circ} \mathrm{C}\end{array}$ \\
\hline $\begin{array}{l}614.28 \\
613.86\end{array}$ & $\begin{array}{l}614 \\
614\end{array}$ & $\begin{array}{l}\text { 2-methyl-3-buten-2-ol } \\
\text { Ethyl acetate }\end{array}$ & $\begin{array}{c}\text { Earthy, fruity, herbaceous, oily, sweet } \\
\text { Acidic, butter, caramelized, ethereal, fruity, } \\
\text { orange, pineapple }\end{array}$ & $\begin{array}{l}\text { Figure 6: (b) } \mathrm{D}^{*}-50^{\circ} \mathrm{C} \text {; } \\
\text { Figure 7: (b) } \mathrm{D}^{*}-80^{\circ} \mathrm{C}\end{array}$ \\
\hline 632.11 & $\begin{array}{l}636 \\
627\end{array}$ & $\begin{array}{l}\text { 1-butamine } \\
\text { Propyl formate }\end{array}$ & $\begin{array}{c}\text { Alcoholic, bitter, chemical, glue, licorice, } \\
\text { solvent, winey } \\
\text { Berry, ethereal, green, sweet }\end{array}$ & Figure 5: (b) B/G \\
\hline $\begin{array}{l}660.89 \\
665.16 \\
\end{array}$ & $\begin{array}{l}662 \\
664\end{array}$ & $\begin{array}{c}\text { 2-methylbutanal } \\
\text { n-butanol }\end{array}$ & $\begin{array}{l}\text { Almond, cocoa, green, malty, strong burnt } \\
\text { Cheese, fermented, fruity }\end{array}$ & $\begin{array}{l}\text { Figure 5: (b) B/G-50 }{ }^{\circ} \mathrm{C} \text {; } \\
\text { Figure 6: (b) } D^{*}-50{ }^{\circ} \mathrm{C} ; \\
\text { Figure } 7:(b, d) D^{*}-80{ }^{\circ} \mathrm{C}\end{array}$ \\
\hline 680.81 & $\begin{array}{l}681 \\
684\end{array}$ & $\begin{array}{l}\text { 1- penten-3-one } \\
\text { Pent-1-en-3-ol }\end{array}$ & $\begin{array}{c}\text { Fishy, fruity, leather, plastic, pungent, rotten, } \\
\text { sewer, spicy } \\
\text { Butter, green, milky, pungent }\end{array}$ & Figure $7:$ (b) $D^{*}-80^{\circ}$ \\
\hline $\begin{array}{l}803.41 \\
803.46\end{array}$ & $\begin{array}{l}801 \\
801\end{array}$ & $\begin{array}{l}\text { 2-hexanol } \\
\text { Hexanal }\end{array}$ & $\begin{array}{c}\text { Fatty, fruity, winey } \\
\text { Acorn, fatty, fishy, grassy, green, herbaceous, } \\
\text { leafy, tallowy }\end{array}$ & $\begin{array}{l}\text { Figure 6: }(b, d) D^{*}-50^{\circ} \mathrm{C} ; \\
\text { Figure } 7:(b, d) D^{*}-80^{\circ} \mathrm{C}\end{array}$ \\
\hline 818.81 & 819 & $\begin{array}{l}\text { 2,4,5-trimethyl-3-oxazoline } \\
\text { 2- butanone, 3-mercapto- }\end{array}$ & $\begin{array}{c}\text { Musty } \\
\text { Onion, sulfurous }\end{array}$ & $\begin{array}{l}\text { Figure 5: (b) } \mathrm{B} / \mathrm{G}-50^{\circ} \mathrm{C} \text {; } \\
\text { Figure 6: (b) } \mathrm{D}^{*}-50^{\circ} \mathrm{C} ; \\
\text { Figure } 7:(\mathrm{b}) \mathrm{D}^{*}-80^{\circ} \mathrm{C}\end{array}$ \\
\hline 986.50 & 986 & $\begin{array}{l}\text { 3-octanone } \\
\text { 6-methyl-5-hepten-2-one }\end{array}$ & $\begin{array}{c}\text { Butter, herbaceous, resinous } \\
\text { Blackcurrant, boiled fruit, citrus, earthy, } \\
\text { mushroom, rubber }\end{array}$ & $\begin{array}{l}\text { Figure 5: }(\mathrm{b},) \mathrm{B}-50^{\circ} \mathrm{C} ; \\
\text { Figure 6: }\left(\mathrm{b}, \mathrm{D}^{*}-50^{\circ} \mathrm{C}\right.\end{array}$ \\
\hline 1000.93 & $\begin{array}{l}1000 \\
1001\end{array}$ & $\begin{array}{l}\text { 2-octanol } \\
\text { Propyl pentanoate }\end{array}$ & $\begin{array}{l}\text { Fatty, mushroom, oily } \\
\text { Ethereal }\end{array}$ & Figure 7: (b) $\mathrm{D}^{*}-80^{\circ} \mathrm{C}$ \\
\hline $\begin{array}{l}1140.68 \\
1140.88\end{array}$ & $\begin{array}{l}1140 \\
1140\end{array}$ & $\begin{array}{c}\text { Homofuraneol } \\
\text { Methyl 3-pyridinecarboxylate }\end{array}$ & $\begin{array}{c}\text { Caramelized } \\
\text { Herbaceous, sweet, tobacco }\end{array}$ & Figure 5: (b) $\mathrm{G}-50^{\circ} \mathrm{C}$ \\
\hline 1286.41 & 1287 & Isoborneol, acetate & Balsamic & $\begin{array}{l}\text { Figure 5: (b) G-50 }{ }^{\circ} \mathrm{C} \text {; } \\
\text { Figure 6: (b) } \mathrm{D}^{*}-50^{\circ} \mathrm{C} \text {; } \\
\text { Figure 7: (d) } \mathrm{D}^{*}-80^{\circ} \mathrm{C}\end{array}$ \\
\hline $\begin{array}{l}1312.65 \\
1312.50\end{array}$ & $\begin{array}{l}1313 \\
1312\end{array}$ & $\begin{array}{l}\text { 1-ethylnapththalene } \\
\text { Cinamyl alcohol }\end{array}$ & $\begin{array}{c}\text { Earthy, green, musty, naphthyl } \\
\text { Oily }\end{array}$ & Figure 5: $(b) B / G-,50{ }^{\circ} \mathrm{C}$ \\
\hline $\begin{array}{l}1399.81 \\
1400.26\end{array}$ & $\begin{array}{l}1400 \\
1400\end{array}$ & $\begin{array}{l}\text { Tetradecane } \\
\text { Diphenyl ether }\end{array}$ & $\begin{array}{l}\text { Alkane, fusel, mild herbaceous, sweet } \\
\text { Green }\end{array}$ & $\begin{array}{l}\text { Figure 5: (b) B/G-50 }{ }^{\circ} \mathrm{C} \text {; } \\
\text { Figure 6: (b) } \mathrm{D}^{*}-50{ }^{\circ} \mathrm{C}\end{array}$ \\
\hline 1414.33 & $\begin{array}{l}1414 \\
1415\end{array}$ & $\begin{array}{l}\text { Linalyl butanoate } \\
\text { (e)-beta-damascone }\end{array}$ & $\begin{array}{l}\text { Floral, Pear, sweet } \\
\text { Apple }\end{array}$ & $\begin{array}{l}\text { Figure 5: (d) } \mathrm{B}-80^{\circ} \mathrm{C} ; \\
\text { Figure } 7: \text { (b) } \mathrm{D}^{*}-80^{\circ} \mathrm{C}\end{array}$ \\
\hline 1533.21 & 1532 & $\begin{array}{l}\text { Cadina-1,4-diene } \\
\text { Methyldodecanoate }\end{array}$ & $\begin{array}{c}\text { Fruity, mango, spicy, wood } \\
\text { Coconut, creamy, fatty, fruity, sweet, waxy, } \\
\text { weak waxy }\end{array}$ & $\begin{array}{l}\text { Figure 5: (b) B-50 }{ }^{\circ} \mathrm{C} ; \\
\text { Figure } 7: \text { (b) } D^{*}-80^{\circ} \mathrm{C}\end{array}$ \\
\hline 1691.60 & $\begin{array}{l}1695 \\
1695\end{array}$ & $\begin{array}{c}\text { Beta-Sinensal } \\
\text { Tetradecanenitrile }\end{array}$ & $\begin{array}{l}\text { Sweet } \\
\text { Fresh }\end{array}$ & Figure 7: $(\mathrm{b}){ }^{*} \mathrm{D}-80^{\circ} \mathrm{C}$ \\
\hline 1807.03 & 1808 & Nootkatone & Banana, citrus, grape, sour fruit, spicy, woody & $\begin{array}{c}\text { Figure 5: (b) B-50 }{ }^{\circ} \mathrm{C} ;(\mathrm{d}) \mathrm{B}-80^{\circ} \mathrm{C} ; \\
\text { Figure 6: }(\mathrm{b}) \mathrm{D}^{*}-50{ }^{\circ} \mathrm{C} ; \\
\text { Figure } 7:(\mathrm{b}, \mathrm{d}) \mathrm{D}^{*}-80^{\circ} \mathrm{C}\end{array}$ \\
\hline
\end{tabular}

MXT-5 = Major contributing sensors from column MXT-5 found from the e-nose sample analysis; C-S = Closest sensors from AroChemBase v8 database related to the MXT-5 found. Sensory description = From AroChemBase v8 database related to the MXT-5 found. Discrimination tendency = Existing relation tendency between volatile compounds and discriminating parameters: B = Between batches (batch 1 and 2); $\mathrm{G}=$ Between feeding groups (Control, ZP 2.5\%, and ZP 5.0\%); B/G = Both for batches and feeding group. $\mathrm{D}^{*}=$ Major probability, between storage time ( 0,30 , and 60 days); additionally, probability between feeding group, but less likely. 


\section{Conclusions}

We evaluated the possible alteration of the organoleptic properties of eggs produced by hens (Lohmann Brown Classic) fed with diets containing different doses of an industrial by-product enriched with organic zinc (Zincoppyeast, ZP) - Control 0\%, ZP 2.5\%, and ZP $5.0 \%$. Analyses were performed with a professional human sensory panel and e-tongue and e-nose evaluation. Based on the results of the human sensory analysis, the applied feed supplementation did not show a clear effect on the organoleptic characteristics of boiled and fried eggs. However, in the e-tongue and e-nose analyses, the egg samples showed a certain separation trend, especially between eggs from the Control group and the ZP $5.0 \%$ group. Moreover, in the e-nose analysis, it was clear that the main parameters causing differences in egg quality were derived from storage time (0,30, and 60 days) and days of sample collection, i.e., between batches (two series of experiments from eggs collected in two different periods of time).

Overall, the usage of Zincoppyeast, the applied industrial by-product (yeast biomass), did not cause a clearly detectable effect on the organoleptic parameters of the eggs at the applied doses $(0 \%, 2.5 \%$, and $5 \%$ Zincoppyeast) of feed supplement with the human organoleptic tests, and differentiation with the instruments was only possible because of their high sensitivity and the applied supervised methods.

The complex methodology used in this research (human sensory analysis, e-nose, and e-tongue analysis) has been found to be suitable for assessing the effects of feed on egg quality. In the future, this method should be further tested on more types of raw materials used in feed (e.g., fish oil, rapeseed cake) whose effects on the organoleptic properties (e.g., smell, taste) of laying hens' eggs are well documented.

Author Contributions: Conceptualization: Z.K., G.B., C.P., É.C., I.D.B., M.B. and T.T.; Data curation: Z.G., M.Ü., Z.J.S., I.D.B. and M.B.; Formal analysis: Z.G., H.H., É.C. and T.T.; Funding acquisition: Z.K. and T.T.; Investigation, G.B., C.P., M.Ü., Z.J.S., I.D.B., M.B. and T.T.; Methodology: G.B., C.P., I.D.B., M.B. and T.T.; Project administration: Z.K., G.B., H.H., É.C., M.Ü., Z.J.S. and T.T.; Resources: Z.K. and G.B.; Software: J.P.A.B. and Z.G.; Supervision: Z.K., G.B. and T.T.; Visualization: J.P.A.B. and Z.G.; Writing—original draft: J.P.A.B.; Writing—review and editing: J.P.A.B., Z.K., Z.G., G.B., É.C. and T.T. All authors have read and agreed to the published version of the manuscript.

Funding: This work was funded by the Romanian Executive Agency for Higher Education, Research, Development and Innovation Funding (UEFISCDI) (EUREKA Danube Grant ZINCOPPYEAST-PN III P3-3.5-EUREKA-2017-0004/contract no. 94/2017) and the Hungarian Ministry for Innovation and Technology (EUREKA_16-1-2017-0006, project ID 11700). This project was supported by the European Union and was co-financed by the European Social Fund (grant agreement no. EFOP-3.6.3VEKOP-16-2017-00005).

Institutional Review Board Statement: The laying hen feeding trial was carried out in accordance with the European Commission Council Directive (86/609/EEC) and the Hungarian Act for the Protection of Animals in Research (Article 32 of Act XXVIII).

Informed Consent Statement: Not applicable.

Data Availability Statement: The data presented in this study are available on request from the corresponding author. The data are not publicly available due to privacy and ethical reasons.

Acknowledgments: Authors thank the company AGSIRA SRL for providing samples.

Conflicts of Interest: The authors declare no conflict of interest.

\section{References}

1. Karoui, R.; De Ketelaere, B.; Kemps, B.; Bamelis, F.; Mertens, K.; De Baerdemaeker, J. Eggs and egg products. In Infrared Spectroscopy for Food Quality Analysis and Control; Elsevier Inc.: Amsterdam, The Netherlands, 2009; pp. 399-410. ISBN 978-0-12-374136-3.

2. Huevo, I. El Gran Libro del Huevo, 1st ed.; EDITORIAL EVEREST: Madrid, Spain, 2009; ISBN 978-84-441-0208-5.

3. Betancourt, L.; Díaz, G. Enriquecimiento de huevos con ácidos grasos omega-3 mediante la suplementación con semilla de lino (Linum usitatissimum) en la dieta. MVZ 2009, 14, 1602-1610. 
4. Lima, H.; Souza, L. Vitamin A in the diet of laying hens: Enrichment of table eggs to prevent nutritional deficiencies in humans. World's Poult. Sci. J. 2018, 74, 619-626. [CrossRef]

5. Yu, Q.; Liu, H.; Yang, K.; Tang, X.; Chen, S.; Ajuwon, K.M.; Degen, A.; Fang, R. Effect of the level and source of supplementary dietary zinc on egg production, quality, and zinc content and on serum antioxidant parameters and zinc concentration in laying hens. Poult. Sci. 2020, 99, 6233-6238. [CrossRef]

6. Kaewsutas, M.; Nararatwanchai, T.; Sittiprapaporn, P. The effects of dietary microalgae (Schizochytrium spp.) and fish oil in layers on docosahexaenoic acid omega-3 enrichment of the eggs Original Research Poultry The effects of dietary microalgae (Schizochytrium spp.) and fish oil in layers on docosahex. J. Appl. Anim. Nutr. 2016, 4, 1-6. [CrossRef]

7. Skrajnowska, D.; Bobrowska-Korczak, B. Role of zinc in immune system and anti-cancer defense mechanisms. Nutrients 2019, 11, 2273. [CrossRef] [PubMed]

8. Trumbo, P.; Yates, A.A.; Schlicker, S.; Poos, M. Dietary Reference Intakes for Vitamin A, Vitamin K, Arsenic, Boron, Chromium, Copper, Iodine, Iron, Manganese, Molybdenum, Nickel, Silicon, Vanadium, and Zink. J. Am. Diet. Assoc. 2001, 101, $294-301$. [CrossRef]

9. Hara, T.; Takeda, T.; Takagishi, T.; Fukue, K.; Kambe, T.; Fukada, T. Physiological roles of zinc transporters: Molecular and genetic importance in zinc homeostasis. J. Physiol. Sci. 2017, 67, 283-301. [CrossRef]

10. Mao, S.Y.; Lien, T.F. Effects of nanosized zinc oxide and $\gamma$-polyglutamic acid on eggshell quality and serum parameters of aged laying hens. Arch. Anim. Nutr. 2017, 71, 373-383. [CrossRef]

11. Tüzün, A.E.; Olgun, O.; Yildiz, A.Ö. The Effect of High-Level Dietary Supplementation with Different Zinc Sources on Performance, Eggshell Quality and Bone Characteristics in Layer Quails. Agric. Life Life Agric. Conf. Proc. 2018, 1, 176-182. [CrossRef]

12. The European Commission. Commission Implementing Regulation (EU) 2016/1095 of 6 July. Off. J. Eur. Union 2016, 10, 7-27.

13. Scheideler, S.E.; Froning, G.; Cuppett, S. Studies of consumer acceptance of high omega-3 fatty acid-enriched eggs. J. Appl. Poult. Res. 1997, 6, 137-146. [CrossRef]

14. Leeson, S.; Caston, L.; Maclaurin, T. Organoleptic Evaluation of Eggs Produced by Laying Hens Fed Diets Containing Graded Levels of Flaxseed and Vitamin E. Poult. Sci. 1998, 77, 1436-1440. [CrossRef]

15. Gonzalez-Esquerra, R.; Leeson, S. Effect of feeding hens regular or deodorized menhaden oil on production parameters, yolk fatty acid profile, and sensory quality of eggs. Poult. Sci. 2000, 79, 1597-1602. [CrossRef]

16. Coorey, R.; Novinda, A.; Williams, H.; Jayasena, V. Omega-3 Fatty Acid Profile of Eggs from Laying Hens Fed Diets Supplemented with Chia, Fish Oil, and Flaxseed. J. Food Sci. 2015, 80, S180-S187. [CrossRef]

17. Eid, Y.; Kirrella, A.A.; Tolba, A.; El-Deeb, M.; Sayed, S.; El-Sawy, H.B.; Shukry, M.; Dawood, M.A.O. Dietary pomegranate by-product alleviated the oxidative stress induced by dexamethasone in laying hens in the pre-peak period. Animals 2021, 11, 1022. [CrossRef]

18. Moon, Y.-H.; Jung, I.-C. Effect of Citrus Byproduct on Quality and Fatty Acid Composition of Chicken Eggs. J. Life Sci. 2010, 20, 1358-1364. [CrossRef]

19. Omri, B.; Chalghoumi, R.; Izzo, L.; Ritieni, A.; Lucarini, M.; Durazzo, A.; Abdouli, H.; Santini, A. Effect of dietary incorporation of linseed alone or togueter with tomato-red pepper mix on laying hen's egg yolk fatty acids profile and health lipid indexes. Nutrients 2019, 11, 813. [CrossRef]

20. Varzaru, I.; Untea, A.E.; Panaite, T.; Olteanu, M. Effect of dietary phytochemicals from tomato peels and rosehip meal on the lipid peroxidation of eggs from laying hens. Arch. Anim. Nutr. 2020, 75, 18-30. [CrossRef]

21. Swiatkiewicz, S.; Koreleski, J. The use of distillers dried grains with solubles (DDGS) in poultry nutrition. World's Poult. Sci. J. 2008, 64, 257-265. [CrossRef]

22. Cufadar, Y.; Göçmen, R.; Kanbur, G. The effect of replacing soya bean oil with glycerol in diets on performance, egg quality and egg fatty acid composition in laying hens. Animal 2016, 10, 19-24. [CrossRef]

23. Fontinele, G.S.P.; Leite, S.C.B.; Cordeiro, C.N.; De Castro Goulart, C.; Costa, A.C.; Neves, J.O.; Silva, J.D.B. Glycerin from biodiesel in the feeding of red-egg layers. Semin. Ciênc. Agrár. 2017, 38, 1009-1016. [CrossRef]

24. Yu, P.; Low, M.Y.; Zhou, W. Design of experiments and regression modelling in food flavour and sensory analysis: A review. Trends Food Sci. Technol. 2018, 71, 202-215. [CrossRef]

25. Hayat, Z.; Cherian, G.; Pasha, T.N.; Khattak, F.M.; Jabbar, M.A. Sensory evaluation and consumer acceptance of eggs from hens fed flax seed and 2 different antioxidants. Poult. Sci. 2010, 89, 2293-2298. [CrossRef]

26. Kalus, K.; Konkol, D.; Korczyński, M.; Koziel, J.A.; Opaliński, S. Laying hens biochar diet supplementation-Effect on performance, excreta $\mathrm{N}$ content, $\mathrm{NH}_{3}$ and VOCs emissions, egg traits and egg consumers acceptance. Agriculture 2020, $10,237$. [CrossRef]

27. Ghasemi-Varnamkhasti, M.; Apetrei, C.; Lozano, J.; Anyogu, A. Potential use of electronic noses, electronic tongues and biosensors as multisensor systems for spoilage examination in foods. Trends Food Sci. Technol. 2018, 80, 71-92. [CrossRef]

28. Alpha MOS. Heracles Manual; Alpha MOS: Toulouse, France, 2018; pp. 1-163.

29. Baldwin, E.A.; Bai, J.; Plotto, A.; Dea, S.; Citrus, U.; Ave, S.N.W.; Haven, W. Electronic Noses and Tongues: Applications for the Food and Pharmaceutical Industries. Sensors 2011, 11, 4744-4766. [CrossRef]

30. Alpha MOS. Electronic Tongue; Alpha MOS: Toulouse, France, 2021. 
31. Wang, Q.; Jin, G.; Jin, Y.; Ma, M.; Wang, N.; Liu, C.; He, L. Discriminating eggs from different poultry species by fatty acids and volatiles profiling: Comparison of SPME-GC/MS, electronic nose, and principal component analysis method. Eur. J. Lipid Sci. Technol. 2014, 116, 1044-1053. [CrossRef]

32. Adamiec, J.; Dolezal, M.; Míková, K.; Davídek, J. Changes in egg volatiles during storage. Food Sci. 2002, 20, 79-82. [CrossRef]

33. Yimenu, S.M.; Kim, J.Y.; Kim, B.S. Prediction of egg freshness during storage using electronic nose. Poult. Sci. 2017, 96, 3733-3746. [CrossRef] [PubMed]

34. Cherian, G.; Goeger, M.P.; Ahn, D.U. Dietary Conjugated Linoleic Acid with Fish Oil Alters Yolk n-3 and Trans Fatty Acid Content and Volatile Compounds in Raw, Cooked, and Irradiated Eggs. Poult. Sci. 2002, 81, 1571-1577. [CrossRef]

35. Ghisellini, P.; Cialani, C.; Ulgiati, S. A Review on Circular Economy: The Expected Transition to a Balanced Interplay of Environmental and Economic Systems. J. Clean. Prod. 2016, 114, 11-32. [CrossRef]

36. De Castro, L.A.; Lizi, J.M.; das Chagas, E.G.L.; de Carvalho, R.A.; Vanin, F.M. From Orange Juice By-Product in the Food Industry to a Functional Ingredient: Application in the Circular Economy. Foods 2020, 9, 593. [CrossRef] [PubMed]

37. Council of the European Communities. Council Directive 86/609/EEC; ECC: Brussels, Belgium, 1986; Volume 358, pp. 1-28.

38. The Parliament. Act XXVIII of 1998 on the Protection and Sparing of Animals; FAOLEX Database: Budapest, Hungary, 2021.

39. National Research Council. Nutrient Requirements of Poultry, 9th ed.; National Academies Press: Washington, DC, USA, 1994; Volume 74, ISBN 0309048923.

40. Aurand, L.W.; Woods, A.E.; Wells, M.R. Sampling and proximate analysis. In Food Composition and Analysis; Springer: Dordrecht, The Netherlands, 1987; pp. 19-34. ISBN 978-94-015-7398-6.

41. AOAC. Official Methods of Analytical Methods of Analysis; AOAC International: Washington, DC, USA, 2006.

42. MSZT Sensory Examination. Methodology. General Instructions. MSZ ISO 6658:2018; Hungarin Standards Institution (MSZT): Budapest, Hungary, 2003.

43. Madsen, B.S. Statistics for Non-Statisticians; Springer: Berlin/Heidelberg, Germany, 2011; ISBN 9783642176555.

44. R Core Team. R: A language and environment for statistical computing. In R Foundation for Statistical Computing; R Core Team: Vienna, Austria, 2020.

45. Umano, K.; Hagi, Y.; Shoji, A.; Shibamoto, T. Volatile Compounds Formed from Cooked Whole Egg, Egg Yolk, and Egg White. J. Agric. Food Chem. 1990, 38, 461-464. [CrossRef]

46. Matiella, J.; Hsieh, T. Volatile Compounds in Scrambled Eggs. J. Food Sci. 1991, 56, 387-390. [CrossRef]

47. Xiang, X.; Wang, Y.; Yu, Z.; Ma, M.; Zhu, Z.; Jin, Y. Non-destructive characterization of egg odor and fertilization status by SPME/GC-MS coupled with electronic nose. J. Sci. Food Agric. 2019, 99, 3264-3275. [CrossRef]

48. Macleod, A.J.; Cavea, S.J. Volatile Flavour Components of Eggs. Sci. Food Agric. 1975, 26, 351-360. [CrossRef] 